\title{
Perceptual Diagnostic Algorithm and its Spectrum without Sensory Stimulus: A Tool for Screening Patients
}

\author{
Faranak Farzadi ${ }^{1 *}$, Akram Jahangir ${ }^{2}$, Jila Sadighi ${ }^{1}$, Aliashghar asgharnejad farid ${ }^{3}$, Hamed Aliakbarzadeh ${ }^{4}$, Afsoon \\ Aeenparast ${ }^{1}$, Shabnam Sedaghati ${ }^{5}$, Aliasghar Haeri Mehrizi ${ }^{1}$, Ramin Mozafari Kermani ${ }^{1}$, Fateme Riyazi ${ }^{1}$ \\ 1. Health Metrics Research Center, Iranian Institute for Health Sciences Research, ACECR, Tehran, Iran \\ 2. Faculty of nursing, Aja University of Medical Sciences, Tehran, Iran \\ 3. School of behavioral sciences and mental health, Iran University of medical sciences, Tehran, Iran \\ 4. Academic center for education, culture and research (ACECR), Tehran, Iran \\ 5. Iranian Epilepsy Association, Tehran, Iran
}

Received: 28 September 2021

Accepted for publication: 13 December 2021

[EPub a head of print-18 December 2021]

Payesh: 2021; 20 (6): 703- 718

\begin{abstract}
Objective (s): Evidences from various studies through the world reports experiences similar to hallucinations in people without a specific disease. This perception is called extrasensory perception, pseudo hallucination and paranormal cognition in scientific-research texts. The incidence and prevalence of extrasensory perception in different societies and the lack of information in educational programs of health service providers, indicate the necessity of appropriate criteria for diagnosing extrasensory perception from hallucinations and other sensory perception disorders. Differences in the causes and management of these situations increase the necessity of the issue.

Methods: Review and qualitative study methods were used in different steps of the study. In the review study, relevant information was collected from scientific sources in the field of psychiatry and psychology and in the field of Islamic philosophy and mysticism. During a series of expert panels and based on documents from review study, different states of perception were identified and a "perceptual diagnostic algorithm and its spectrum without sensory stimulus" were designed.

Results: Perceptual diagnostic algorithm is a tool to distinguish a person with experience of extrasensory perception from people with sensory perception disorders as well as normal sensory perception.

Hallucination, extrasensory perception and revelation are categorized as perceptual experiences without the presence of sensory stimuli. These situations Based on these characteristics: awareness of the presence or absence of sensory stimuli, physical and mental health of the experiencer, awareness of the message of perceptual experience forms the spectrum of perception without sensory stimuli.

Conclusion: The use of "perceptual diagnostic algorithm" and its spectrum without sensory stimulus" by physicians, psychiatrists, psychologists, and counselors can meet the need to diagnose various sensory-related conditions in health system.
\end{abstract}

Keywords: extrasensory perception, pseudo hallucination, false hallucination, diagnostic algorithm, perception spectrum

\footnotetext{
* Corresponding author: Health Metrics Research Center, Iranian Institute for Health Sciences Research, ACECR, Tehran, Iran

E-mail: faranakfarzadi@yahoo.com
} 


\section{الكوريتم تشخيص ادر اك و طيف ادراك بدون محرك حسى: ابزارى براى غربالكرى}

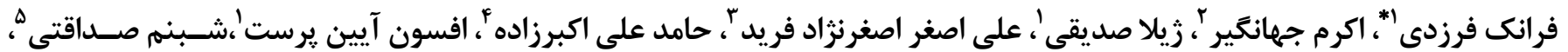

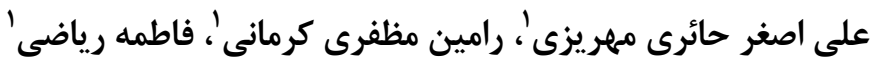

I. مركز تحقيقات سنجش سلامت، يُوهشكده علوم بهداشتى جهاد دانشَاهى، تهران، ايران

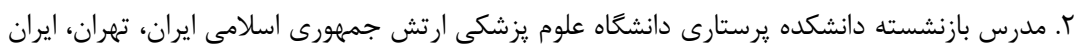

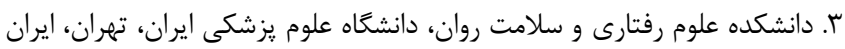

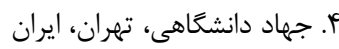

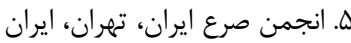

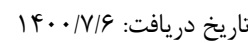

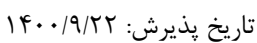

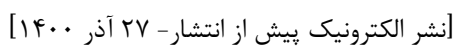
نشريه קايش:

جكيده

مقدمه: شواهد حاصل از مطالعات مختلف در سطح جهانى، تجربيات مشابه توهم در افراد بدون بيمارى خاص را گزارش مىنمايند. از اين حالـت ادراك، بـاـ

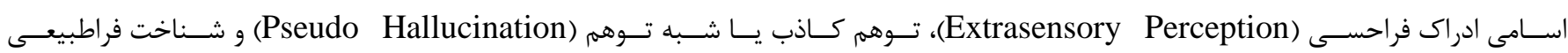
(Paranormal Cognition)

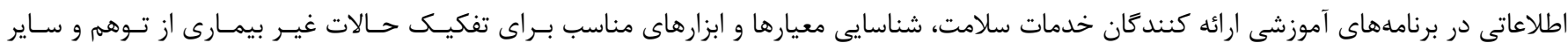

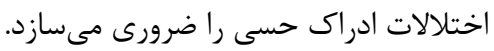
مواد و روش كار: در اين يزوهش از مطالعات كتابخانهاى و كيفى در مراحل مختلف استفاده شد. در مطالعه كتابخانهاى با استفاده از منابع معتبر علمى در حوزه

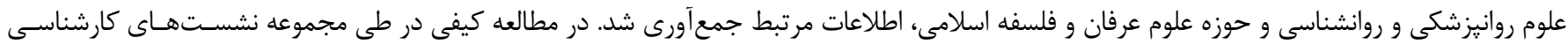

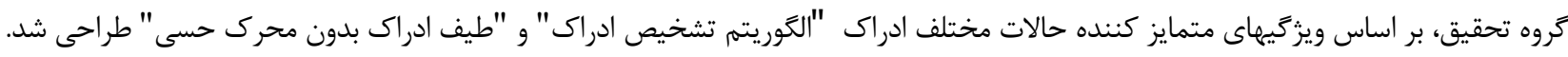

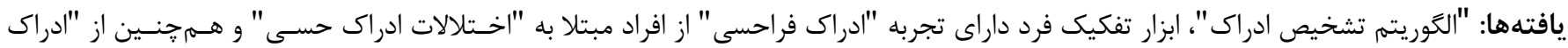

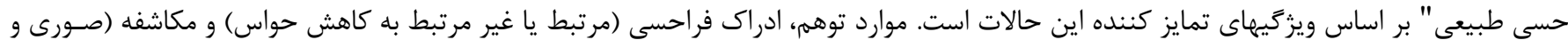

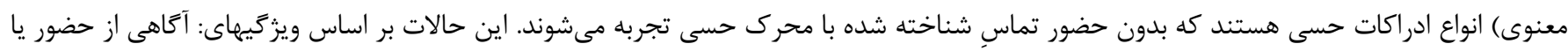

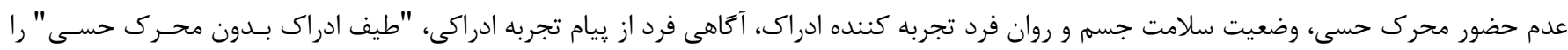
تشكيل مي دهند. نتيجه گَيرى: كاربرد "الخوريتم تشخيص ادراى" و "طيف ادراك بدون محرى حسى" توسط يزشكان، روانيزشكان، روانشناسان و مشاوران مسىتوانـد نيـاز

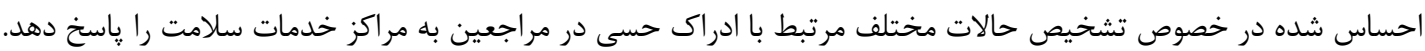
كليد وازه: ادراك فراحسى، شبه توهم، توهم كاذب، الگوريتم تشخيص، طيف ادراك.

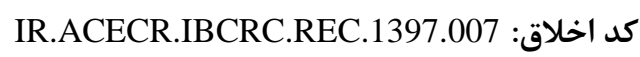


شامل سايكوز، سوء مصرف مواد، اختلالات خواب و ضايعات موضعى

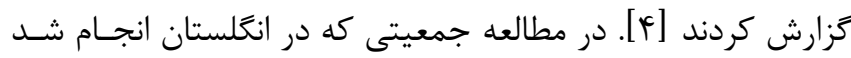
VD درصد افراد داراى تجربه توهمى سالم و فاقد معيارهاى سـايكوز

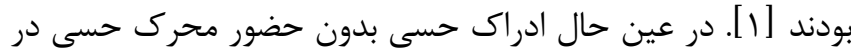

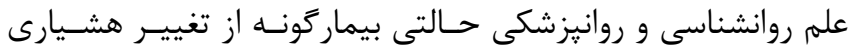

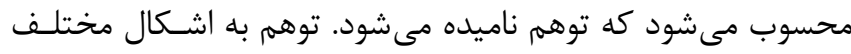

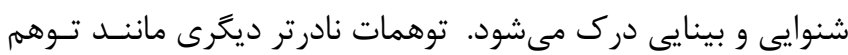

بويايى و لامسه نيز وجود دارند [و-هـ].

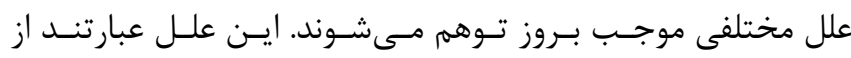

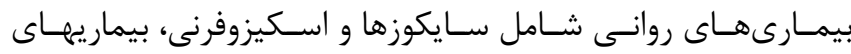

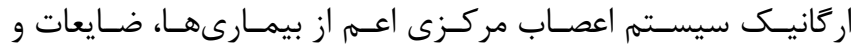

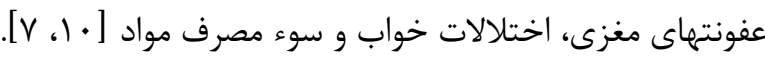

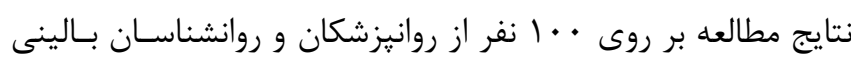

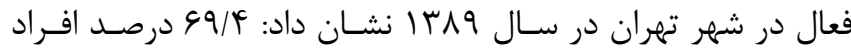
مورد مطالعه، تجربه توهمى در فردى بدون بيمارى خاص درا را محتمل

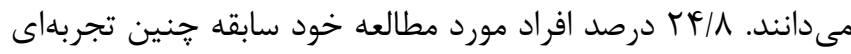
را ذكر كردند. اما فقط צب درصد اين افراد در تشخيص افتراقى خود

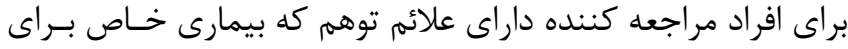

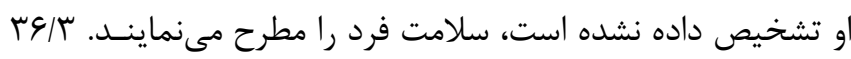

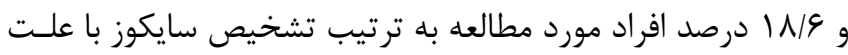

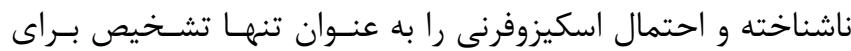

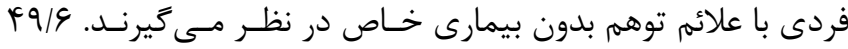

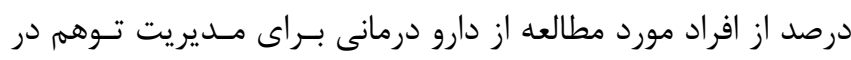

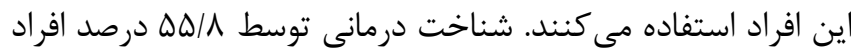

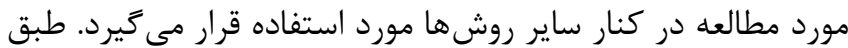

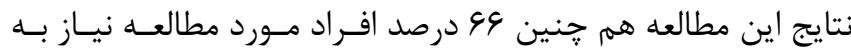

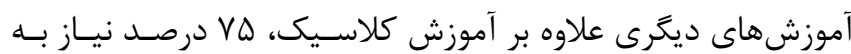
ضرورت تفكيك تجارب ماورايى از توهم در طب و و N د درصد نيساز

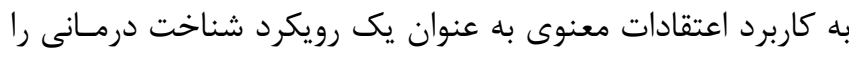

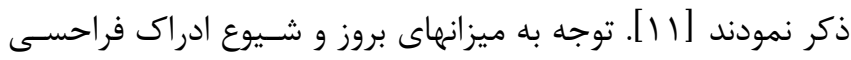
در جوامع مختلف، همجنين خلاء اطلاعاتى در برنامههـاى آموزشى درى

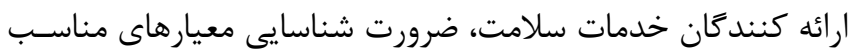

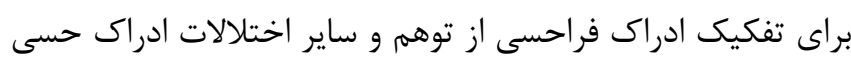

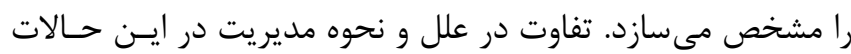

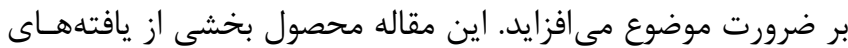

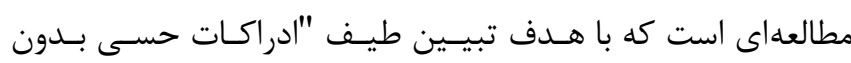

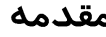

ادراك بخش قابـل توجــهاى از مطالعات و تلاشهاى علمى فيلسوفان

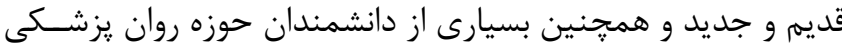
و روانشناسى را به خود اختصاص داده است. جرا كه شناخت اندان انسان از جهان اطراف خود بواسطه ادراك است. از آنجا كه سازعارى انسان

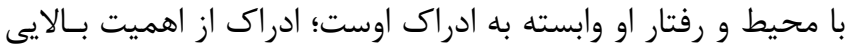

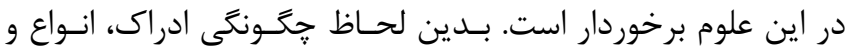
حالات مختلف و هم جنين اختلالات ادراك از مباحث مههم فكرى و يزوهشى است. ادراك فراحسى طبق تعريف فرهنگستان زبان و ادب

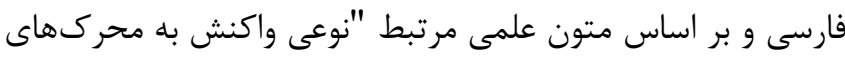

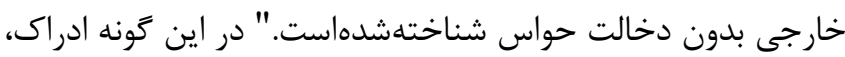

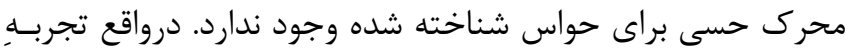

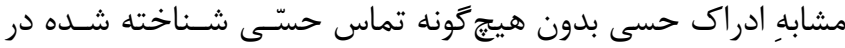

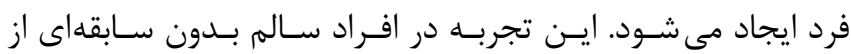

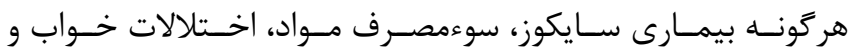
بيمارى هاى ار كانيك سيستم اعصاب مركزى است.

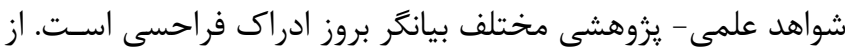

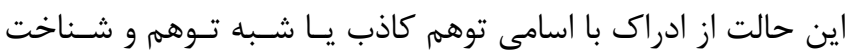

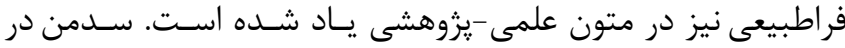

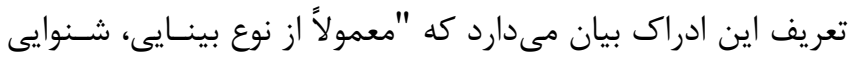

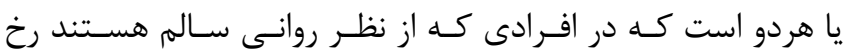

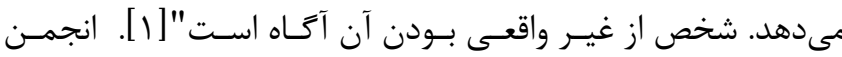

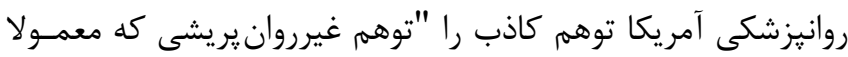
به شكل ديدارى رخ مى دهد و در نظر فرد به عنوان تـوهم شــناخته

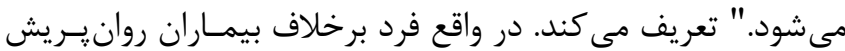

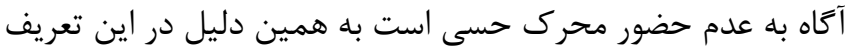

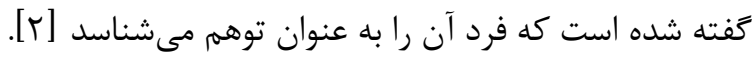
در مطالعهاى كه در سال 1991 بر روى ... سال انجام شد ميزان بروز تجربه توهمى بينايى، ك درصد در مـردان

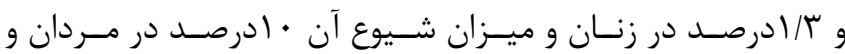

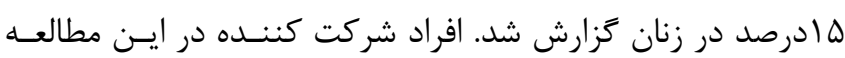

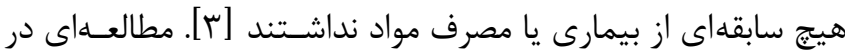

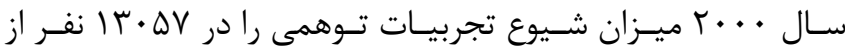

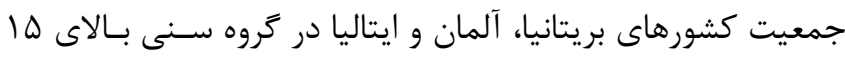

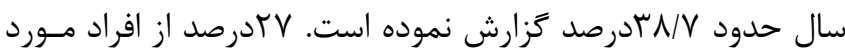

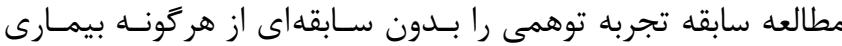


patients and non-patients

توهم، تـوهم بينـايى، تـوهم شــوايى، ادراك حسـى بــدون محــرى

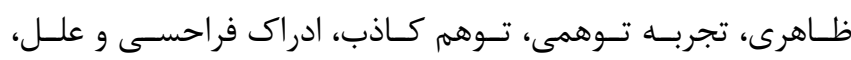

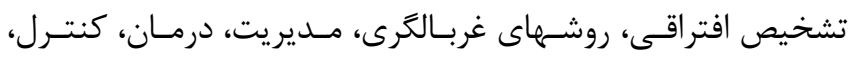

$$
\text { مراقبت، بيمار و غير بيمار }
$$

ب) از بانكهاى داده انگليسى و فارسئ

- CINAHL (Cumulative Index to Nursing \& Allied Health Literature)

-Medline (Medical literature analysis and retrieval system online):

-Ovid's search

\section{- Interface for MEDLINE}

-Scopus (the largest abstract and citation database of peer-reviewed literature)

- National Electronic Library for Health (NeLH)

Scientific Information

Database/SID

(http://www.sid.ir/En/index.asp)

- Iranmedex

- Magiran

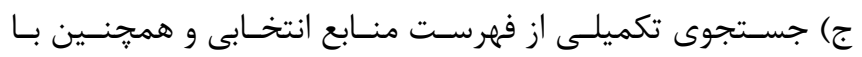

استفاده از موتور جستجوى Google scholar

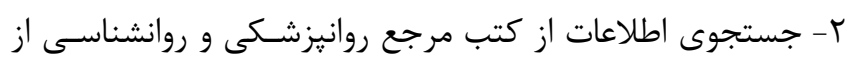

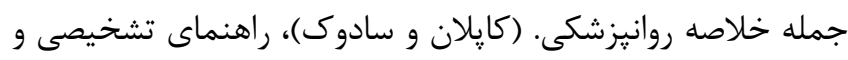

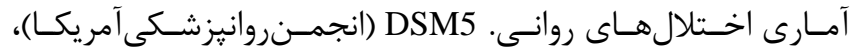

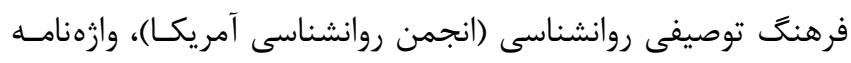

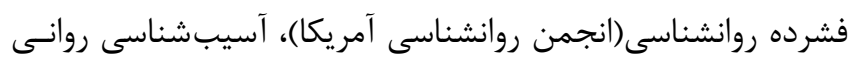

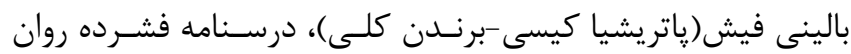

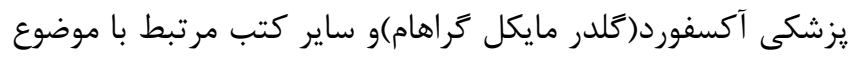
در حوزه روانيزشكى و روانشناسى انجام شدرد

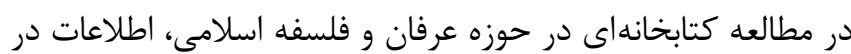

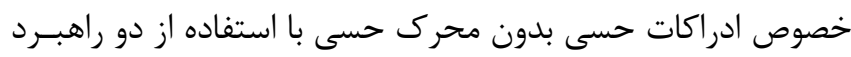

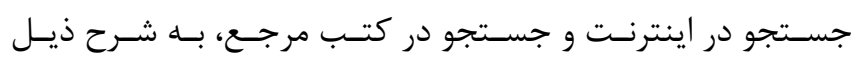
جمع آورى شد. ا - جستجوى اينترنتى با تركيب مناسبى از كليـد وازههـاى ادراك،

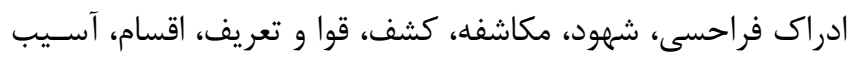

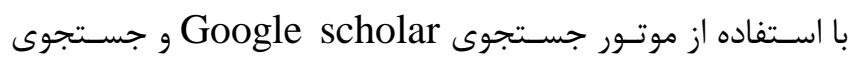
تكميلى از فهرست منابع انتخابى انجام شد.

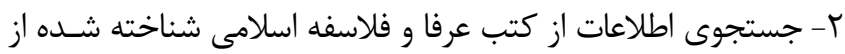
جمله بوعلى سينا، ملاصدرا، ابن عربى و علامه طباطبايى انجام شد.
محركات حسى" و تعيين نحوه مديريت اين نوع ادراكات به منظـور

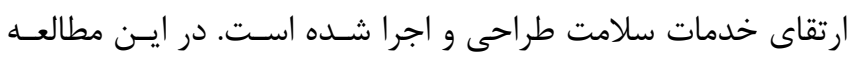

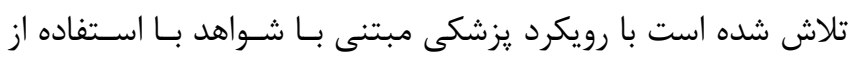

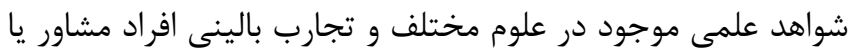

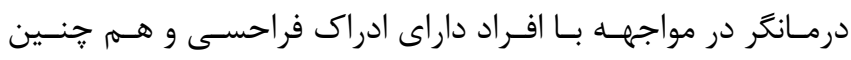

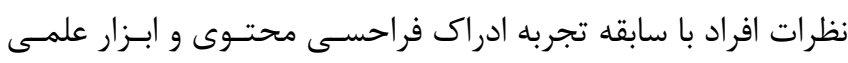

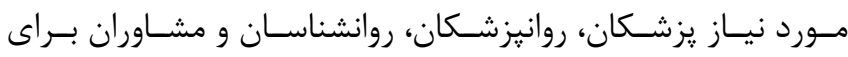

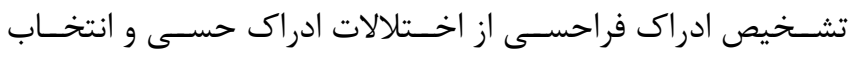

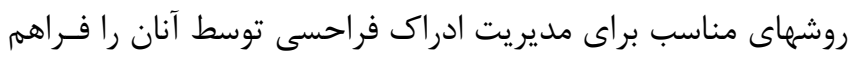

نمايد.

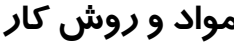

اين مقاله بخشى از يافتههاى يزوهش "بروسى روش روشهاى مدير ماريت

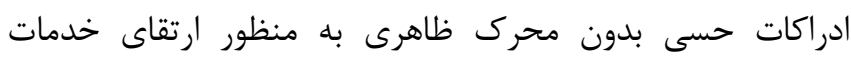

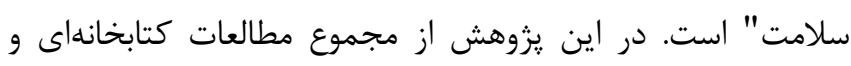

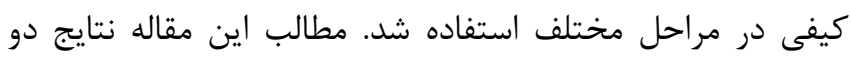
مرحله اول مطالعه به شرح ذيل است. نتايج ساير مراحل در مقالات درئل ديكر منتشر خواهد شد.

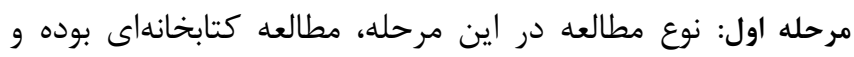
اطلاعات مرتبط با استفاده از منابع معتبر علمى در حرائ حوزه العلوم

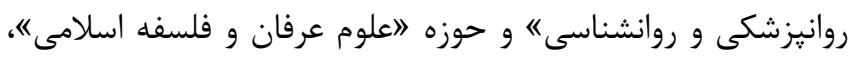

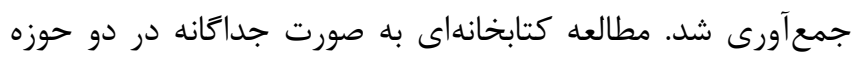
"روانيزشكى و روانشناسى" و "عرفان و فلسفه اسلامى" انجام شد.

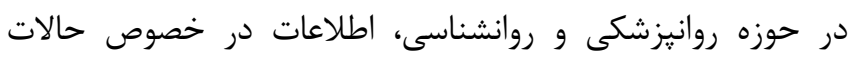

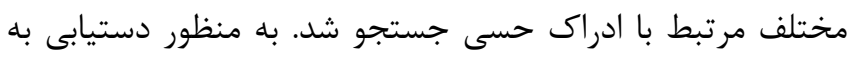

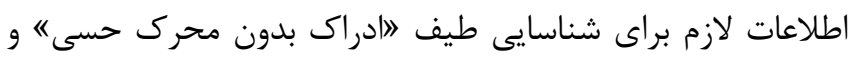

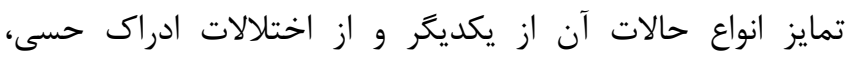

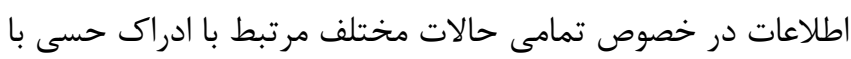

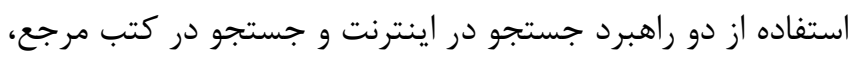
به شرح ذيل جمعآورى شد. 1- جستجوى اينترنتى به شرح زير شير انجام شد.

Sensory perception, Sensory perception disorder, Hallucination, hallucination (e.g. Visual hallucination, auditory hallucination, pseudo hallucination, tactile hallucination, unusual hallucination), Hallucination*(e.g. hallucinatory experience), Unusual perception, \& Definition, differential diagnosis, screening methods, screening tools, management, treatment, care, 
كيرنده حسى، وضعيت انطباق و تناسب با محرك حسىى و وضـعيت آكاهى و سلامت جسم و روان فرد تجربه كننده ادراك حسى وصى اسـت

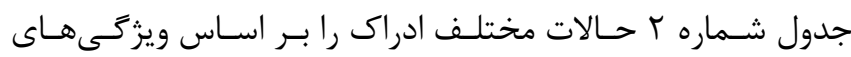

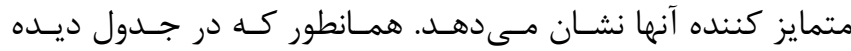
مى شود، با توجه به همسانى ويزگيهاى سندروم جارلز بانت با تجربه

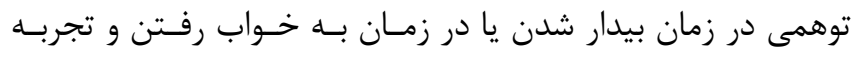
توهمى در زمان كاهش تحريك حسى اين حسالات از تجربـه مشـابه ادراى حسى در يك گروه دستهبنـدى شـدند. بـا توجـهـ بــه تشـابه

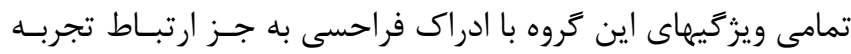

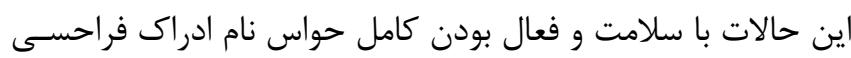
در زمان كاهش حواس بر اين گروه گذاشته شد. اعضاء گروه تحقيق در نشست تخصصى با استفاده از نتايج ارائه شده

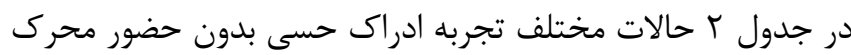

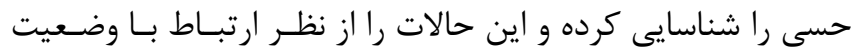

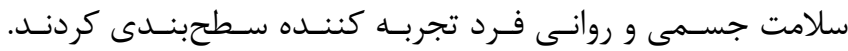
"توهم"، "ادراك فراحسى" و "مكاشفه" حالات مختلـف از تجــارب ادراى حسى بدون حضور محرى حسى هستند. منظـور از محسـرى

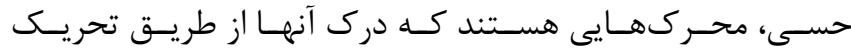

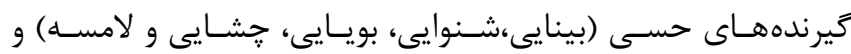

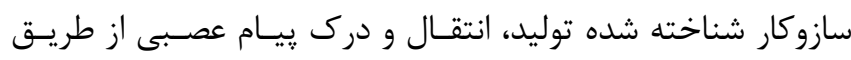

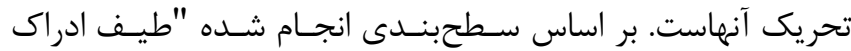

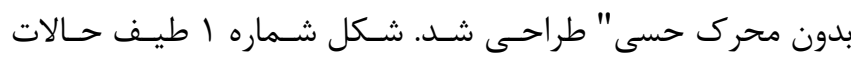

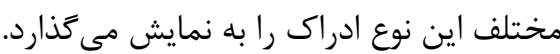

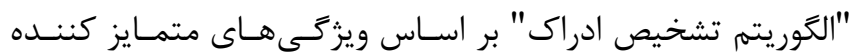
حالات مختلف ادراك، در نشست تخصصى محققان طراحى شد. اين

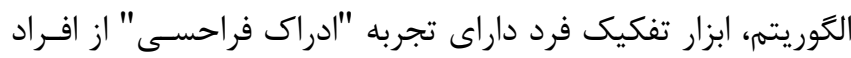

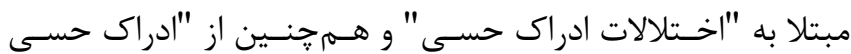

$$
\text { طبيعى" است (شكل باه ). }
$$

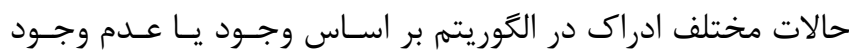

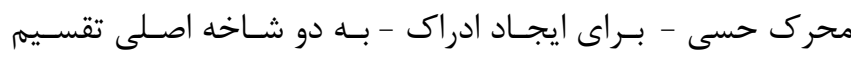

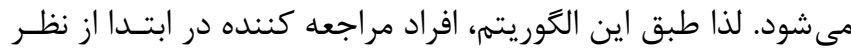

$$
\text { وجود محرك حسى مورد سئوال واقع مىشوند. }
$$

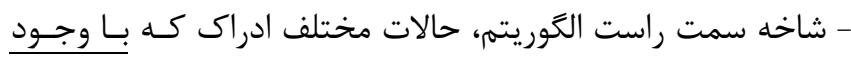
محرك حسى در فرد ايجاد شدهاست را دربرمسى گيـرد. ايسن شـاخه انواع اختلال در نحوه ادراك از محرك حسى شامل "تحريف حسى" و "وهم" را از يكديگر و از "ادراك حسى طبيعى" جدا مى دنمايد.
مرحلــه دوم: نــوع مطالعـهـ در ايسن مرحلـه، كيفـى بـوده و در طـى

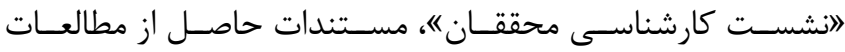
كتابخانهاى مرتبط با دو حوزه "روانيزشكى و روانشناسى" و و "عرفان و فلسفه اسلامى" (نتـايج مرحلـه اول تحقيـق) مـورد بررسـى قـرار گرفت. حالات مختلف مرتبط با ادراك حسى از مجمـوع مسـتندات

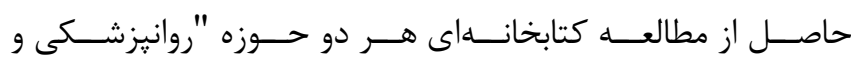
روانشناسى" و "عرفان و فلسفه اسلامى"، شناسايى و تلفيق شـدند. تعاريف از مستندات معتبر براى هر يك از اين حالات مشخص شــــ

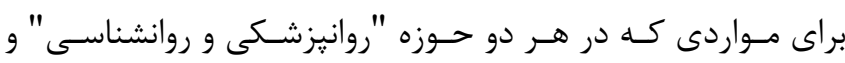
"عرفان و فلسفه اسلامى " مطرح بودند؛ تعاريف از منــابع معتبــر هـر دو حوزه به صورت جداكانه اخذ شد. گروه تحقيق بر اساس تعاريف،

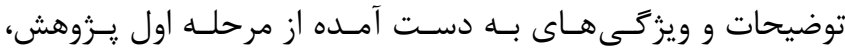
ويزگ كارشناسى محققان شناسايى كرد. ا. تجربه هاى مختلف ادراك بدون حضـور محسـرك ظـاهرى، از نظــر ارتباط بـا وضـعيت سـلامت جسـمى و روانسى فـردِ تجربـه كنـــده، سطحبندى شدند. بر اساس ايـن سـطحبنـدى "طيـف ادراك بـدون محرى حسى " طراحى شد. r. حالات مختلف ادراك بر اساس ويزگ كيهـاى متمــايز كنـــده آنهـا،

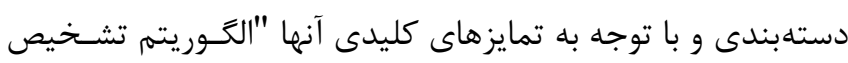

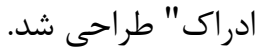

يافتهها بــر اسـاس اطلاعــات موجـود در متـون و مســتندات معتبــر علـوم

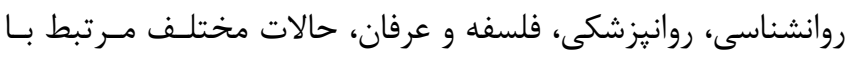
ادراك حسى شناسايى شدند. اين موارد شامل حالات مختلف ادراى رونى حسـى اعـهم از ادراك حسـى طبيعـى، اخــتلالات ادراك حسـى و

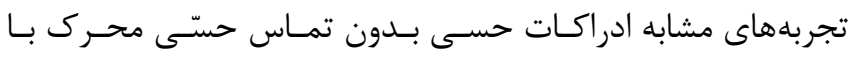
كيرندهاى حسى است. نتايج حاصل از بررسى شواهد علمى موجود در دو حوزه "روانيزشكى و روانشناسى" و "عرفان و فلسفه اسلامى"

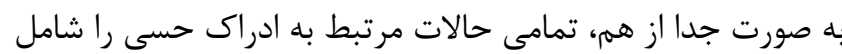

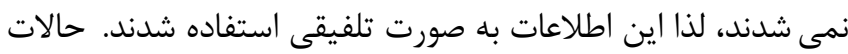
مختلف مرتبط با ادراى حسى همراه بـا تعـاريف بركرفتـهـ از منــابع براى هر يك از اين حالات در جدول ا ارائه شده است. در نشسـت تخصصسى محققـان، معيارهـاى متمـايز كنـــده حـالات مختلف ادراك با استناد به متون علمى شناسايى شدند. اين معيارها

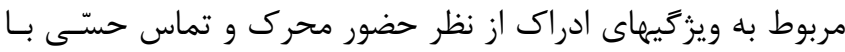


وهم ILLUSION: ادراك حسى در حضـور محـرك حسى ايجـاد

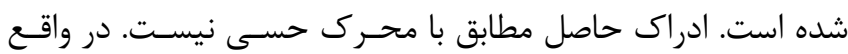

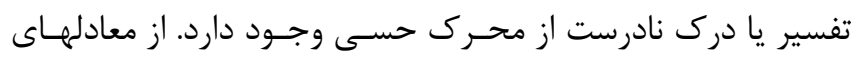

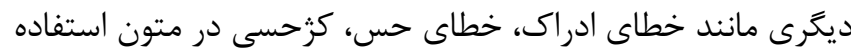

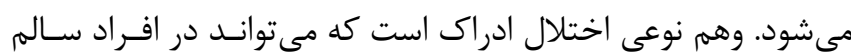

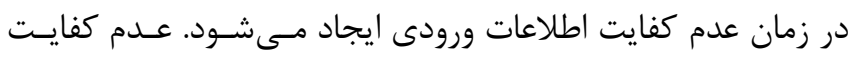

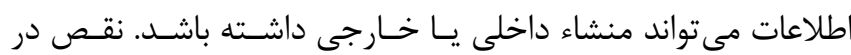

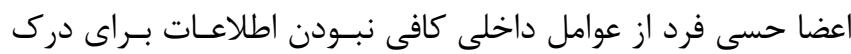

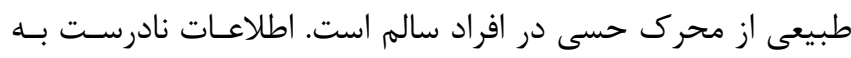

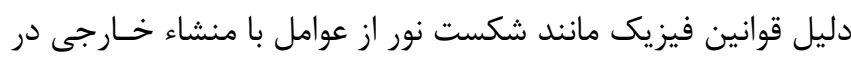

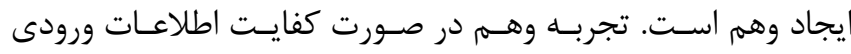
نشانه اختلال در يردازش اطلاعات حسى در سيستم اعصاب مركزى

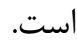

توهم HALLUCINATION: ادراك مشـابه ادراك حسىى، بـدون حضور محرى حسى ايجاد شده است. ادراى از نظر فرد واقعى است

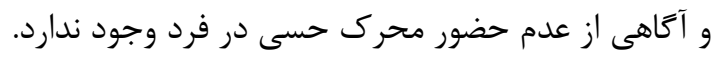

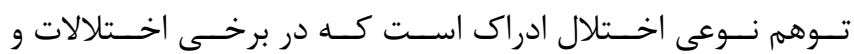
بيمارى هاى جسمى و روانى ديده مىشود. اين اختلالات و بيماريهـا

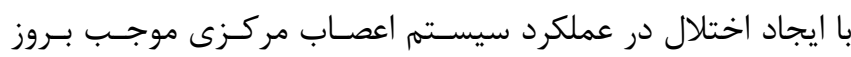

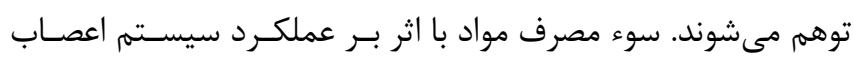
مركزى موجب بروز توهم مىشود.

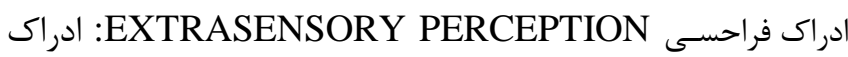
مشابه ادراى حسى، بدون حضور محرى حسى در فر فرد تجربه كننده

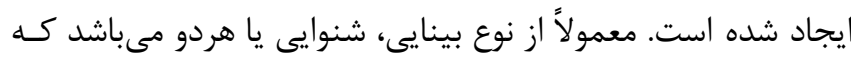

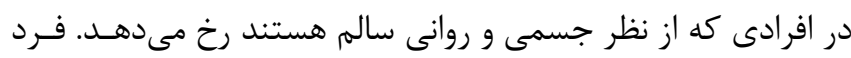
از عدم حضور محرى حسى آدى آكاه است.

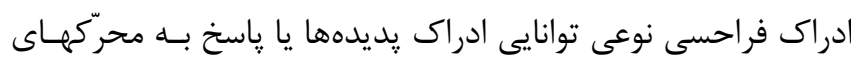

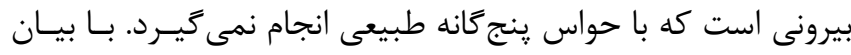

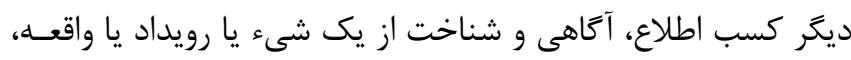

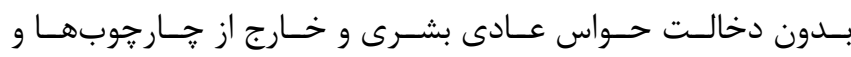
مكانيسه هاى طبيعى در ادراكات حسى، از قبيـل اسـتفاده از زمـان،

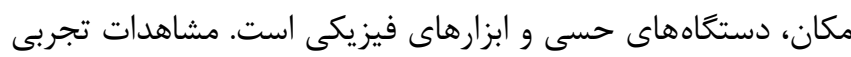

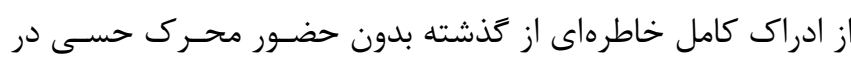

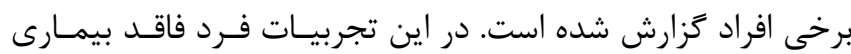
خاص (به معناى هركونه سايكوز، اختلالات خواب، سوء مصرف موات آنداد

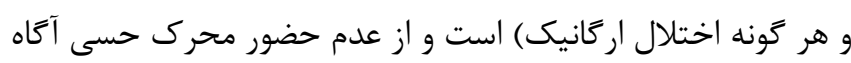

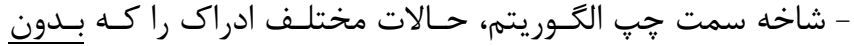

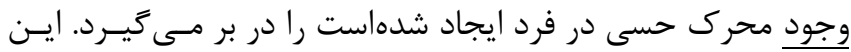

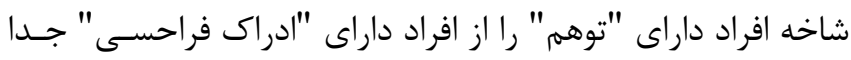
مىنمايد. از آنجا كه بر اساس تعريـف و ويزَّيهـاى مكاشـفه انتظـار

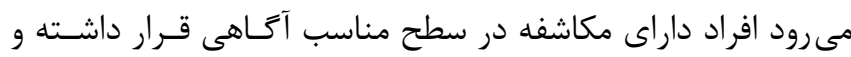

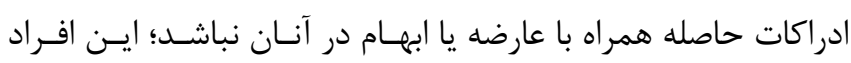

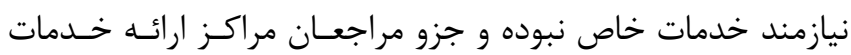

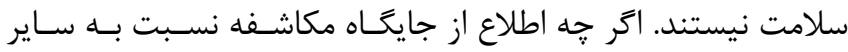

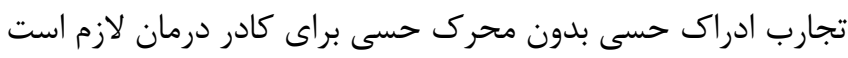

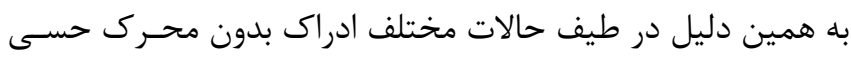

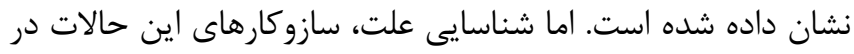

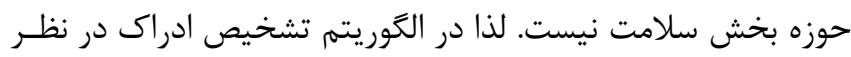

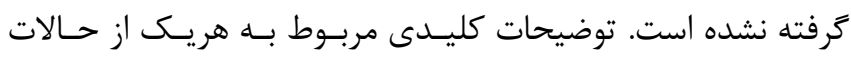

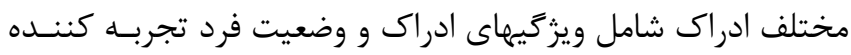

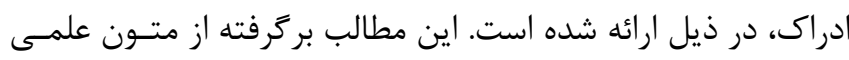
است كه با نظر گروه تحقيق تكميل و اصلاح شده است. ادراك حسى طبيعى NORMAL SENSORY PERCEPTION ادراك حسـى در حضـور محـرك حسى ايجــاد شـده اسـت. ادراك

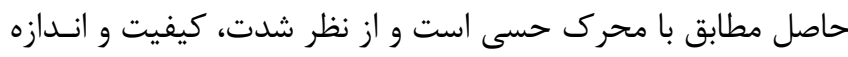
متناسب با محرك حسى است. لازمه جنين ادراكى برخوردارى از سلامت ساختارهاى مرتبط شامل

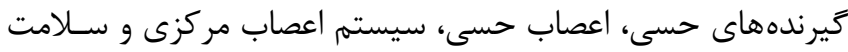

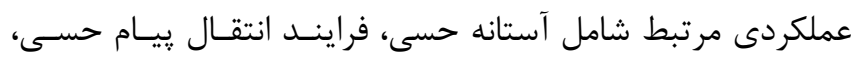

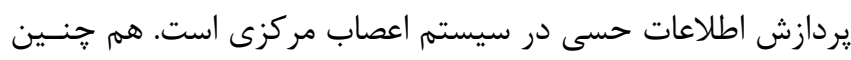
كفايت اطلاعات حسى لازم است.

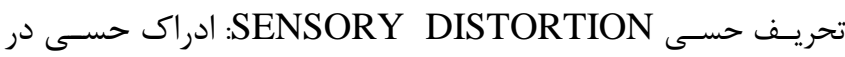

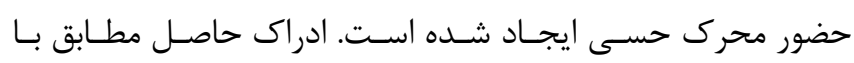

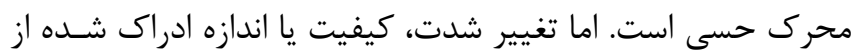

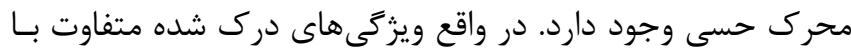
ويزگكيهاى محرك حسى است. تحريف حسى نوعى اختلال ادراك است. اين اختلال إد ادراك مى إتواند

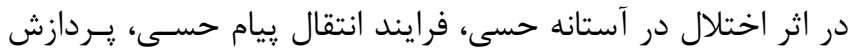

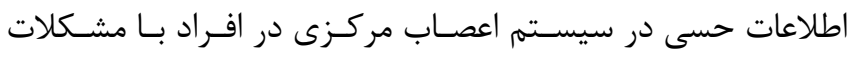

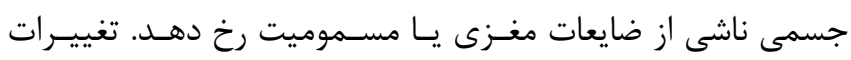

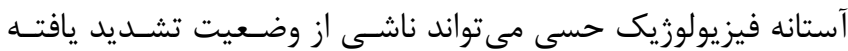

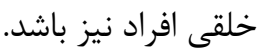


يا بيدار شدن از خواب اطلاق مىشـود. در ايسن حالـت فـرد از عـدم حضور محرى حسى آثاه است. افراد تجربه كننده اين حالـت سـالم

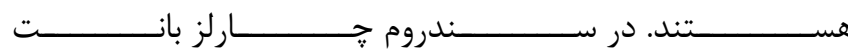
ادراك بينايى با شـفافيتى (CHARLES BONNET SYNDROM) بالا(حتى بالاتر از تصاوير طبيعى) بدون حضور محرك حسـى ايجـاد

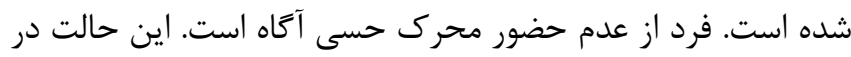
افرادى با كاهش يا فقدان قدرت بينايى در اثر كهولت سن يا آسـيب

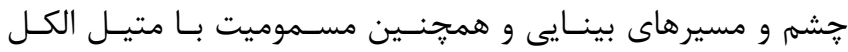

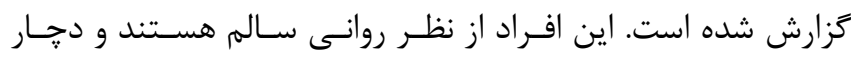

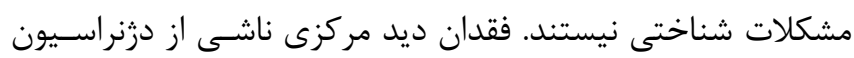
ماكولا يا فقدان ديد محيطى ناشى از كلوكوما مى تواند عامل جنـين ادراكات بينايى شود. سندروم جارلز بانت و تجربه توهمى در زمان بيدار شدن / بـهـ خــواب

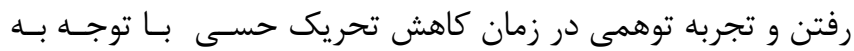

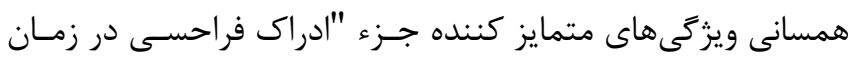
كاهش حواس" قرار كرفتند.
است. خاطره توهمى با توجه به همسانى ويزگى هاى متمـايز كنـــده جزء ادراك فراحسى قرار مى گيرد.

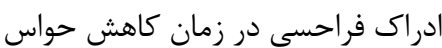
Extrasensory perception at the time of sensory decline: ادراك فراحسى است كه در زمان كاهش حواس در افراد برخوردار از سلامت روان و بدون اختلال شناختى و هوشيارى رخ مى ردهد.

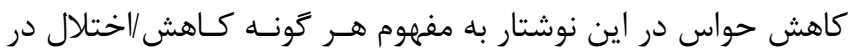
دروندادهاى حسى به كار رفته است كه مسى توانـد ناشسى از كـاهش

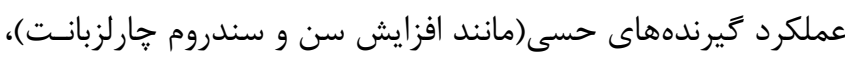
كاهش محركهاى محيطى(مانند زندگى در تنهايى)، قطع تمـاس بـاسـا

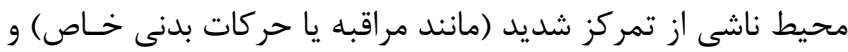

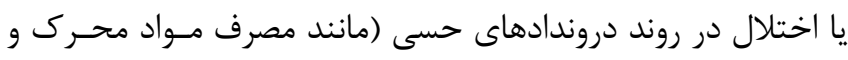

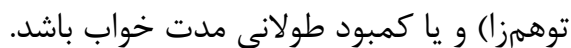

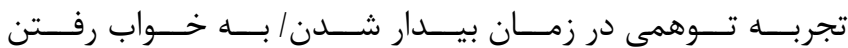
(HYPNOPOMPIC/HYPNAGOGIC) ادراى حسى، بدون حضور محرك حسى در هنعام به خـواب رفـتن

جدول ا: تعاريف حالات مختلف مرتبط با ادراك حسى در حوزه علم روانشناسى و روانيزشكى - فلسفه و عرفان

\begin{tabular}{|c|c|c|c|}
\hline توضيحات & اصطلاح انغَليسى & اصطلاح فارسى & رديف \\
\hline 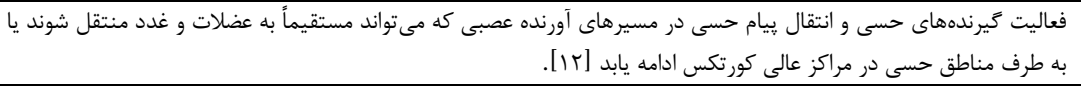 & Sensation & 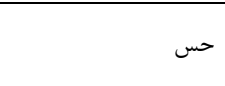 & 1 \\
\hline 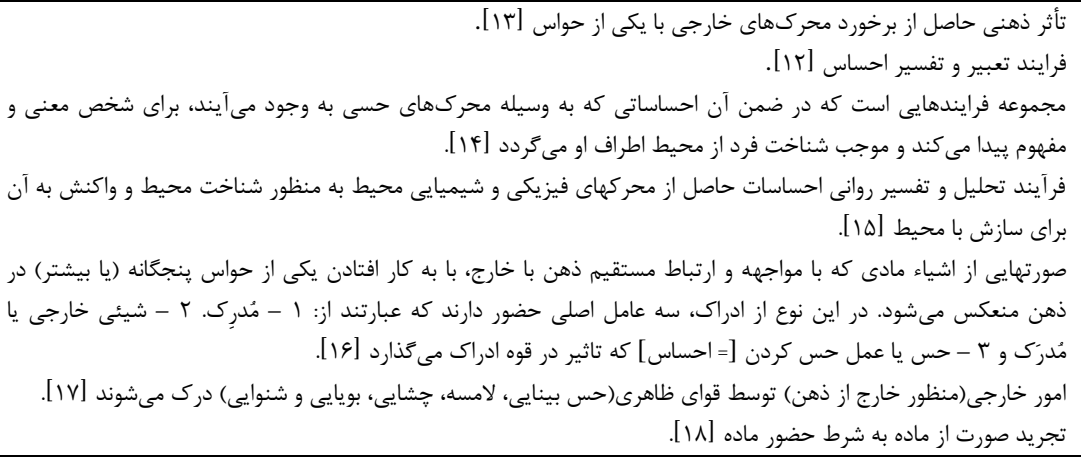 & Sensory perception & ادراك حسى & r \\
\hline 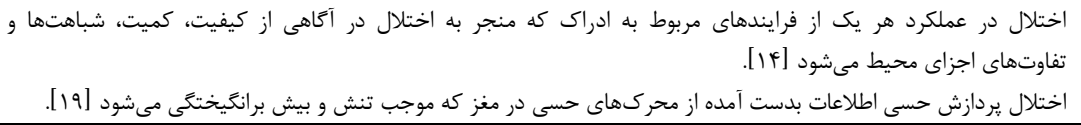 & $\begin{array}{r}\text { Sensory perception } \\
\text { disorder }\end{array}$ & اختلال ادراك حسى & r \\
\hline 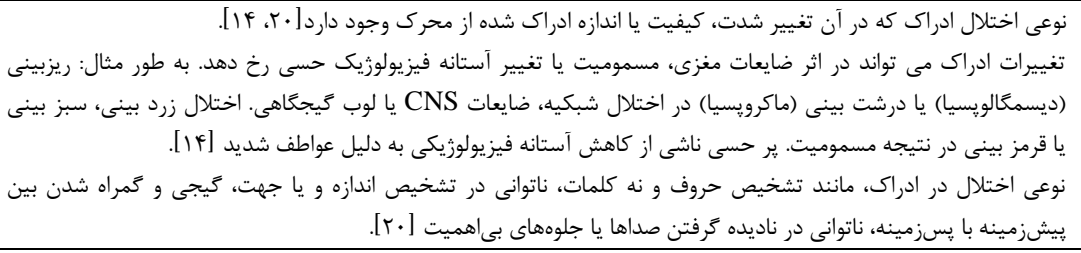 & Sensory distortion & تحريف حسى & f \\
\hline 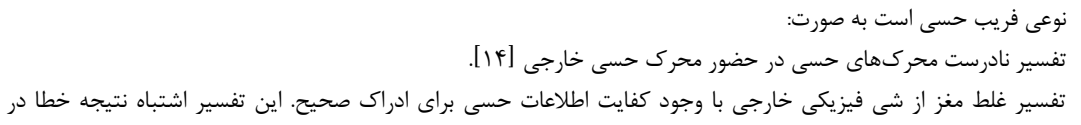 & Illusion & وهماى ادراى/ خطاى & $\Delta$ \\
\hline
\end{tabular}




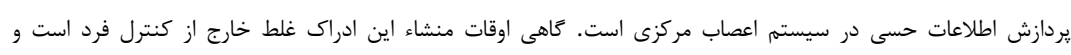

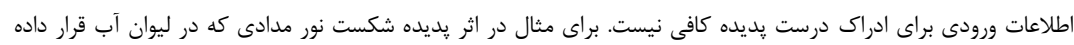

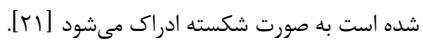

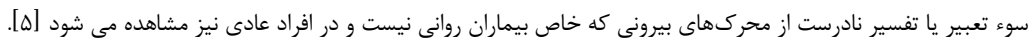

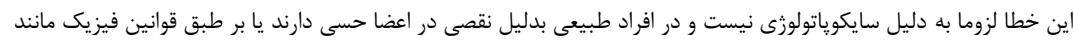

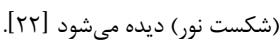

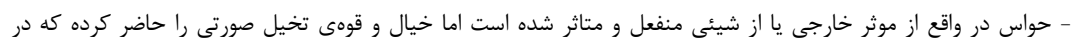

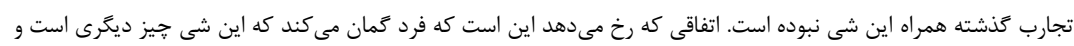

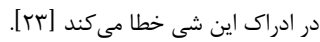

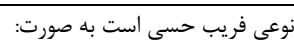

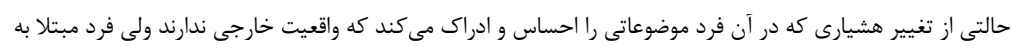

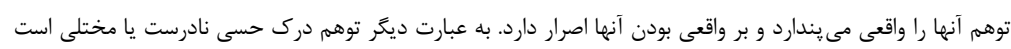

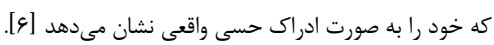

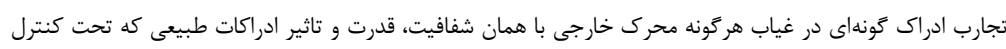
ارادى فرد قرار ندارند [ه]]

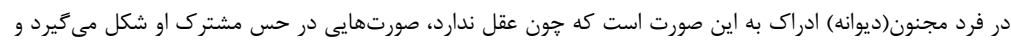

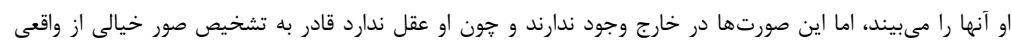

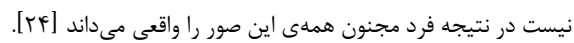

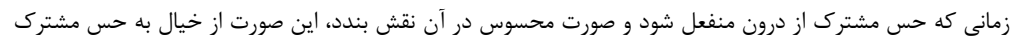

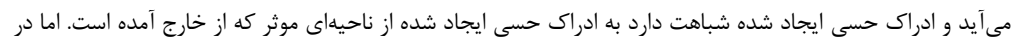

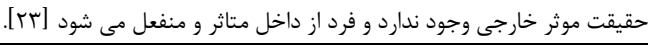

\begin{tabular}{|c|c|c|c|}
\hline 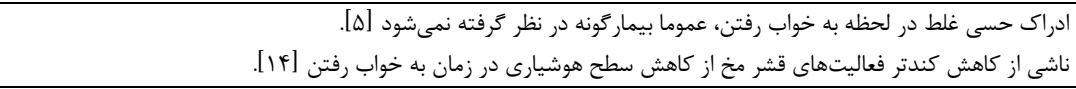 & $\begin{array}{r}\text { Hypnagogic } \\
\text { hallucination }\end{array}$ & توفتهم در زمان به خواب & $\mathrm{v}$ \\
\hline 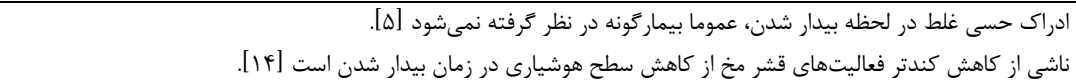 & $\begin{array}{r}\text { Hypnopompic } \\
\text { hallucination }\end{array}$ & شدنه مر زمان بيدار & $\wedge$ \\
\hline 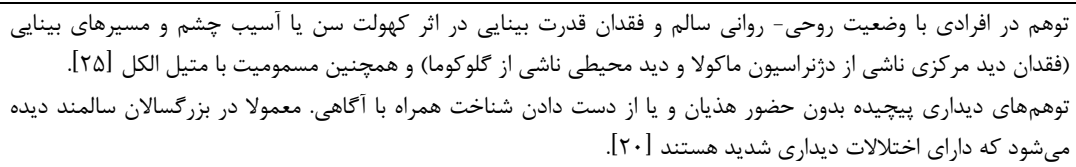 & $\begin{array}{rr}\text { Charles bonnet } \\
\text { syndrome }\end{array}$ & سندرم حارلز بانت & 9 \\
\hline 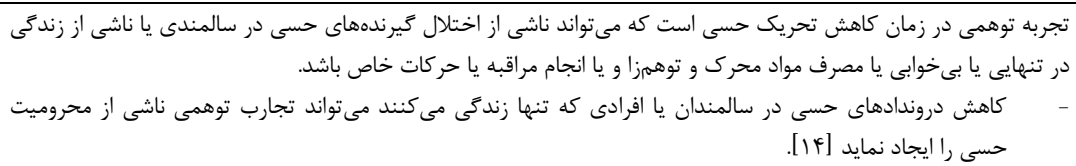 & & & \\
\hline 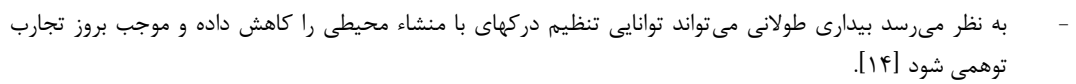 & & كاهش تحريه توهمى حر زمان & \\
\hline - & & & \\
\hline 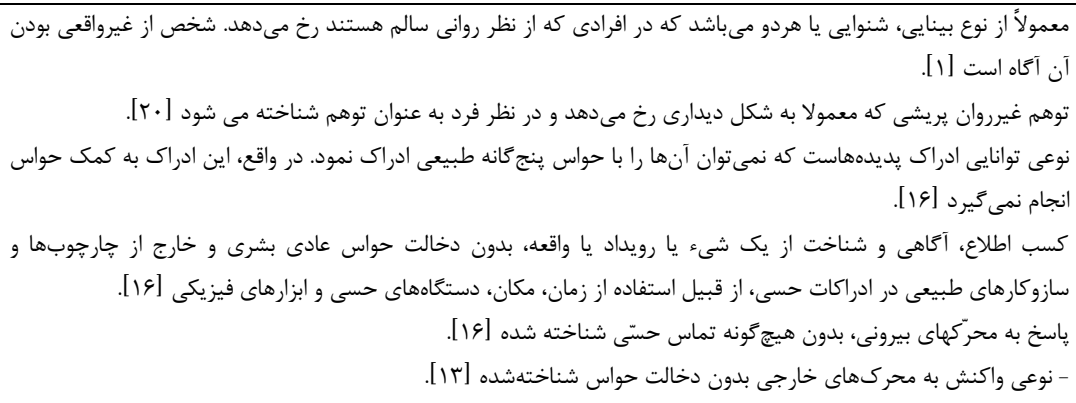 & $\begin{array}{r}\text { Extrasensory } \\
\text { perception } \\
\text { Paranormal ( } \\
\text { cognition / Pseudo } \\
\text { )hallucination }\end{array}$ & شادراى فراحسى (شوهم، كوهم كاذب، & 1. \\
\hline 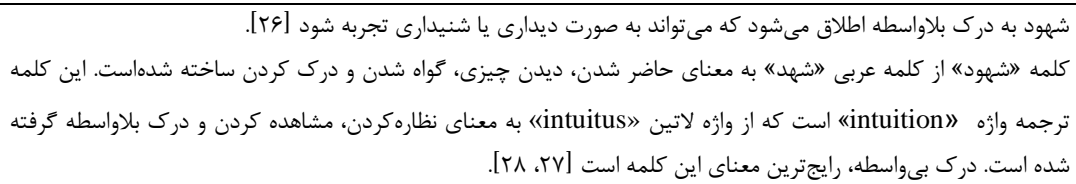 & Intuition & شهود & 11 \\
\hline
\end{tabular}

كاذب/كزحسى)

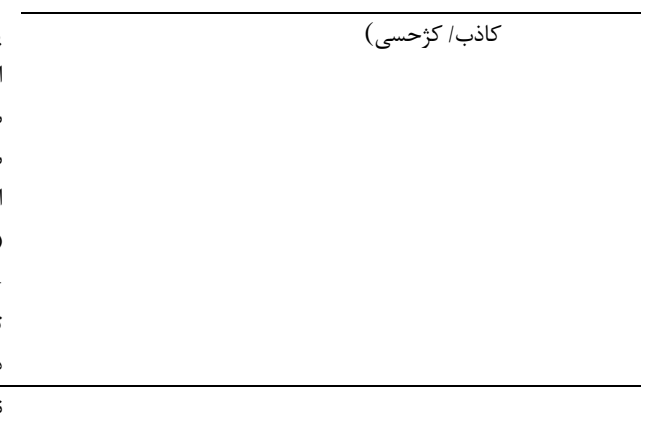


سال بيستم، شماره ششم، آذر -دى .. If

معرفت شهودى است كه ادارك خاصى از راه متمركز كردن توجه به باطن نفس (و نه از راه تجربه حسى و يا راه تحليل عقلى)

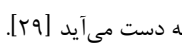

كشف صورى آن نوع مكاشفه است كه در آن صور و حقايق مثالى و برزخى از طريق حواس پنجكًانه براى فرد مكشوف شوند

عارف در اين نوع كشف با حقايق اشياء در عالم مثال در ارتباط است و متوجه مىشود كه تمام اجزاى عالم داراى جشم و كوش إش

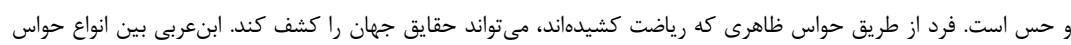
I $\quad$ مكاشفه صورى

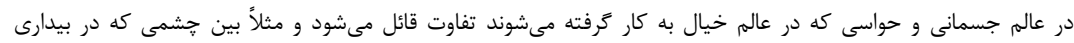

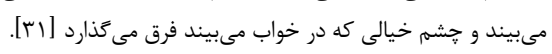

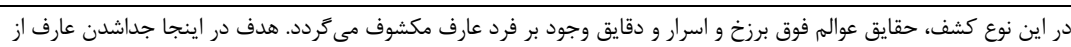

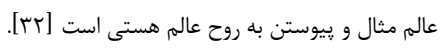

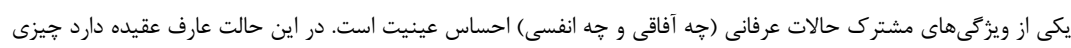

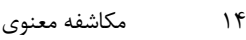

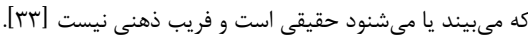

جدول ז: حالات مختلف ادراك به تفكيك ويثگى هاى ادراك و وضعيت فرد

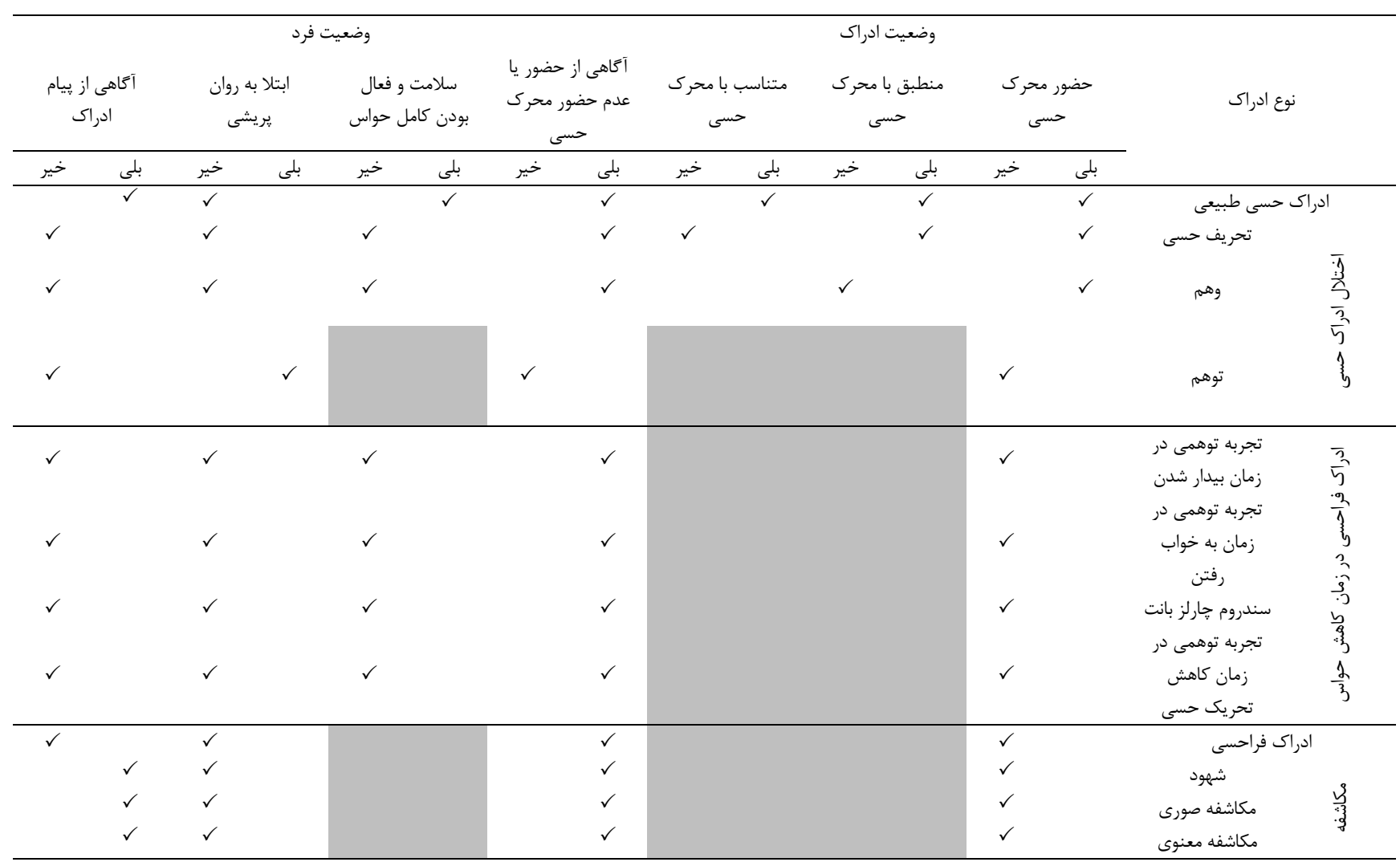


سال بيستم، شماره ششم، آذر - دى ..

شريه يزوهشكده علوم بهداشتى جهاددانشكاهى

شكل ا: طيف ادراك بدون محرى حسى

عدم آكاهى به عدم حضور محرى حسى

لَّاهى به عدم حضور محرى حسى، عدم درك ييام

آكاهى به عدم حضور محرى حسى، درك پيام

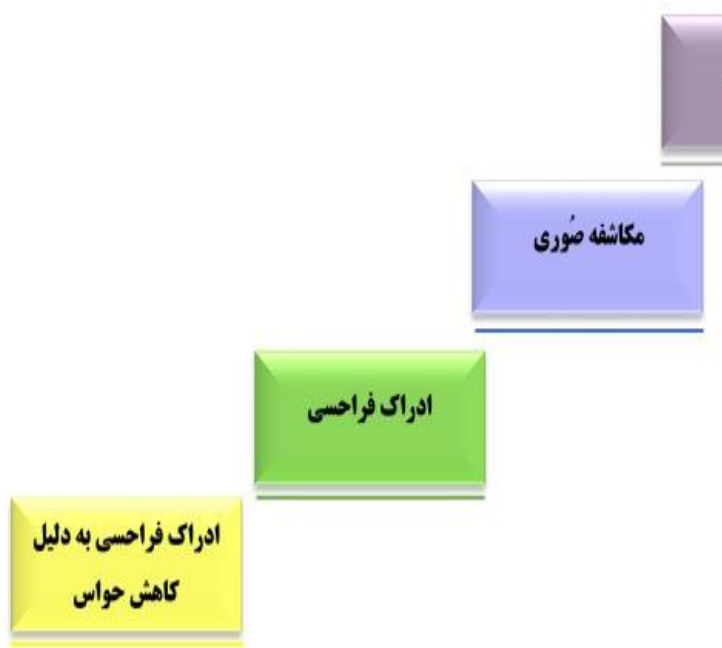

توهم به دليل اختلالات

اركانيك

توهم به دليل اختلالات

سايكوتيك 
سال بيستم، شماره ششم، آذر ـدى ..1f

$\underbrace{4}_{-4}$

شكل ז:الكوريته تشخيص ادراك

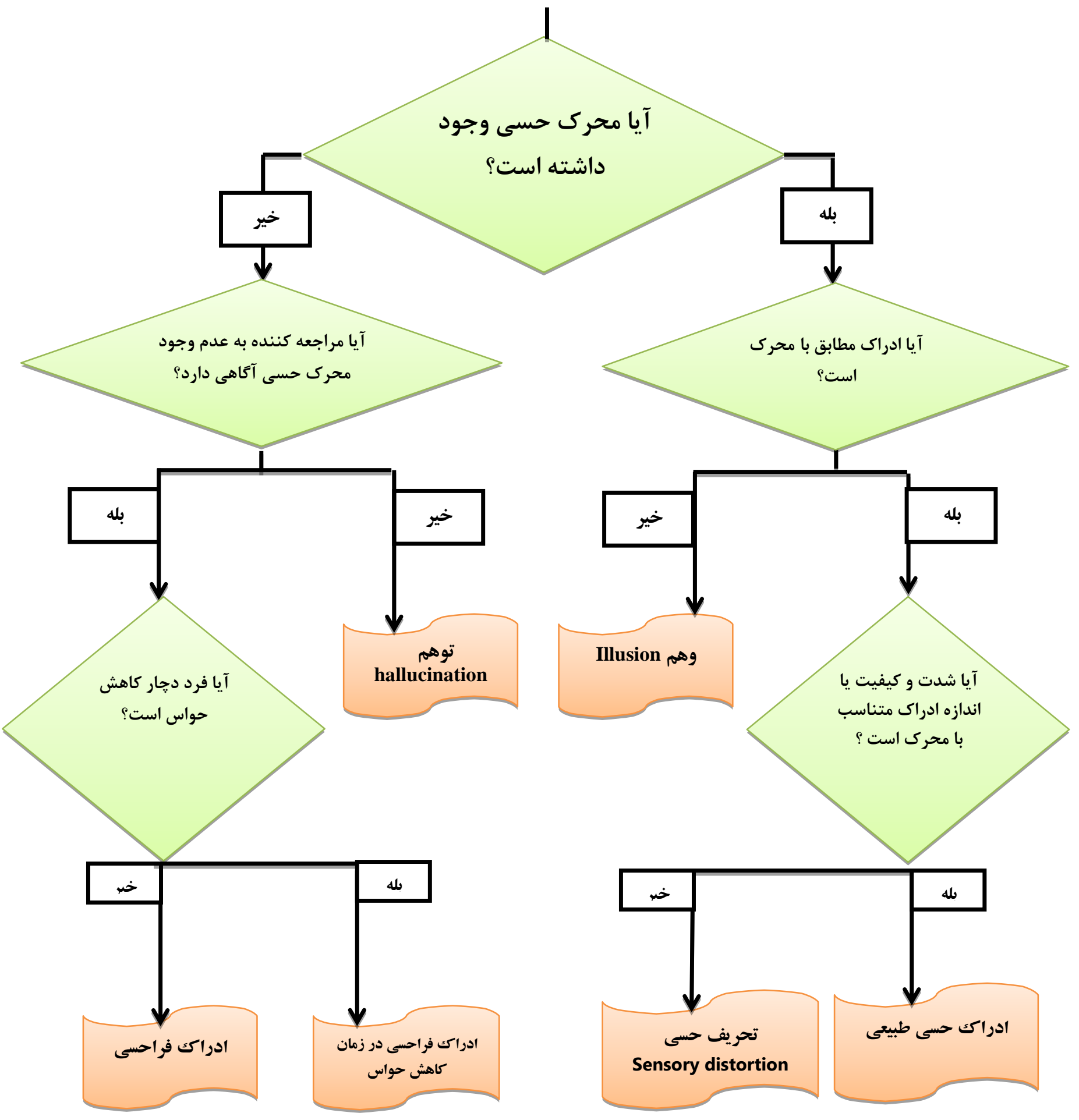


اين ادراك به كمك حواس انجام نمى گيرد. كسب اطـلاع، آَكـاهى و

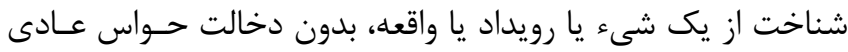

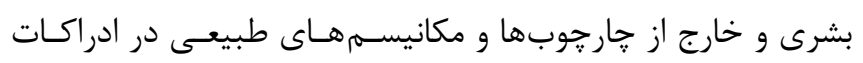

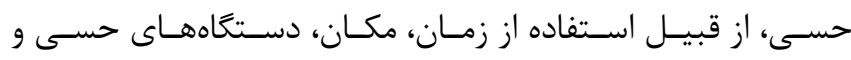

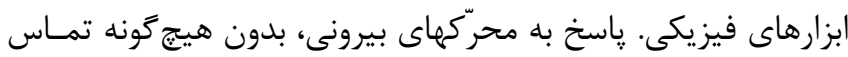

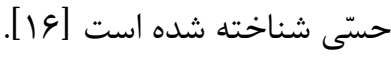

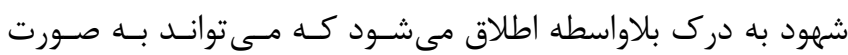

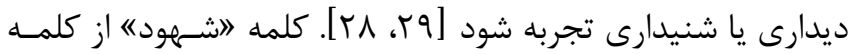

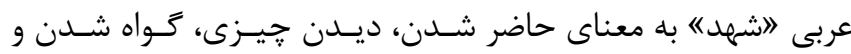

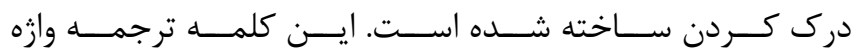

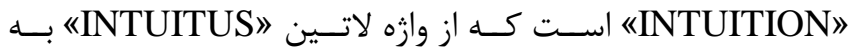
معناى نظاره كردن، مشاهده كـردن و درك بلاواسـهه كرفتـه شـــه

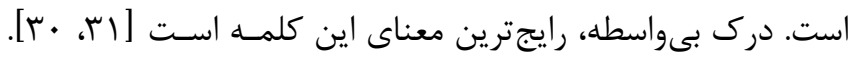

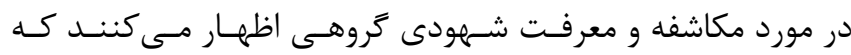

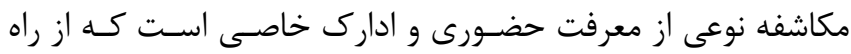

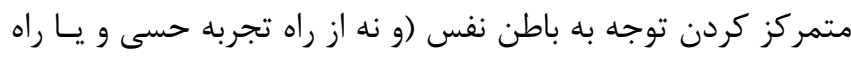
تحليل عقلى) به دست مى آيد. در جريان اين سير و سلوك، معمـولا

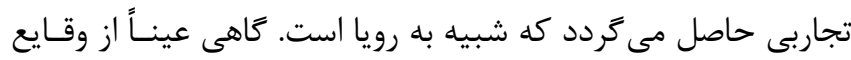

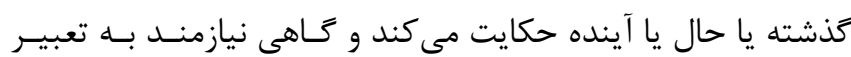

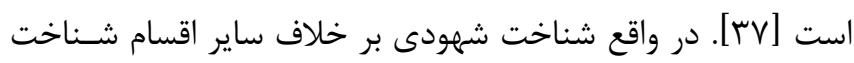

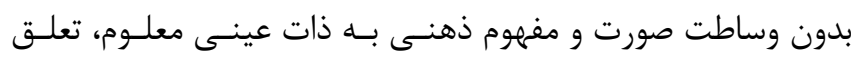

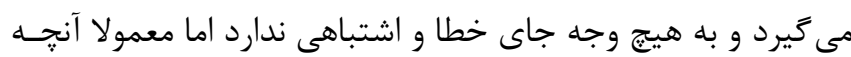

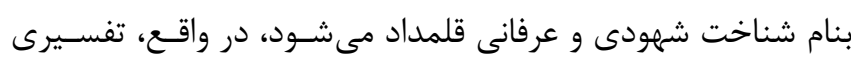

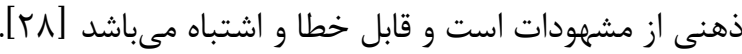
از آنجايى كه مكاشفه معرفت شهودى حاصل از سير وسلوك اسـت؛

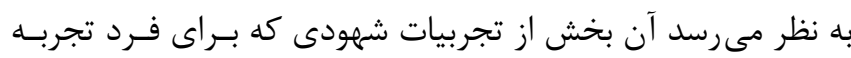

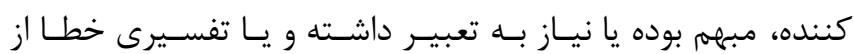
مشهودات در فرد ايجاد مى كند جزء ادراكات فراحسى است.

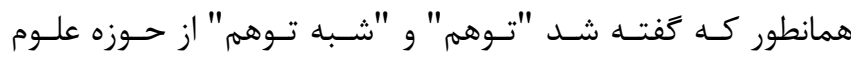

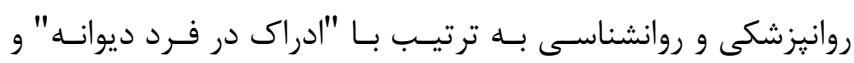

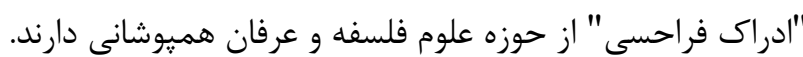

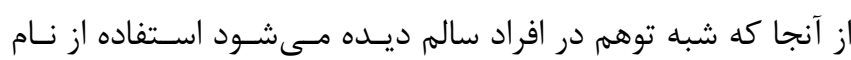

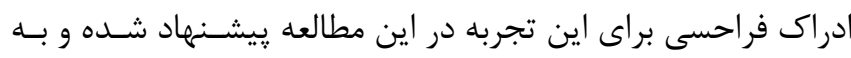

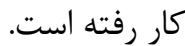

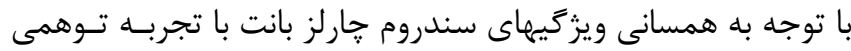

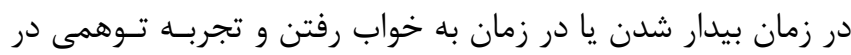

\section{بحث و نتيجه گيرى}

در اين مطالعه تلاش شده است تا با شناخت حالات مختلف مـرتبط

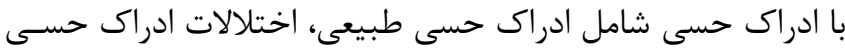

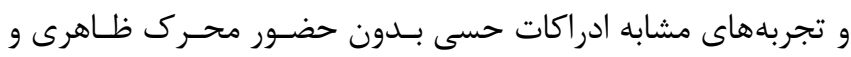
تماس حسّى محرك با كيرندههاى حسى در افـراد سـالم، اطلاعـات إندات

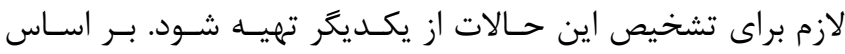

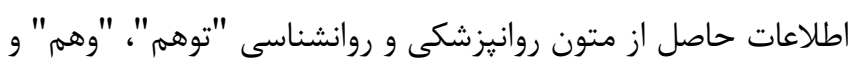

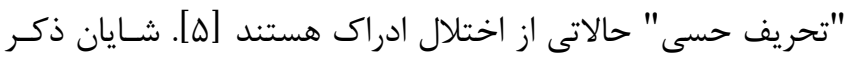

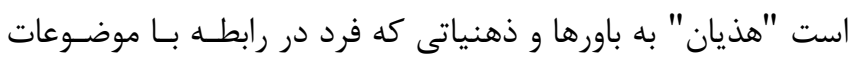

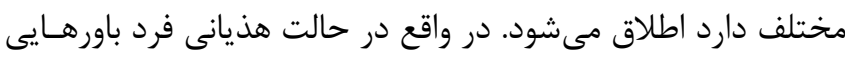

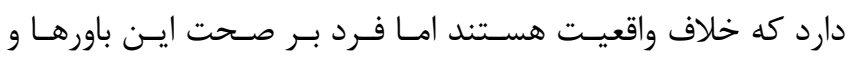

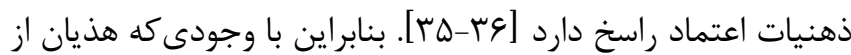
نشانه هاى اساسى در تشخيص اختلالات روانى شديد مثل سايكوزها

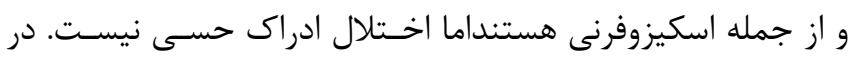
هذيان هيج نوع ادراك حسى به طور مثال شنوايى يا بينايى تجربـهـ نمىشود. لذا در اين مطالعه به هذيان يرداخته نشده است.

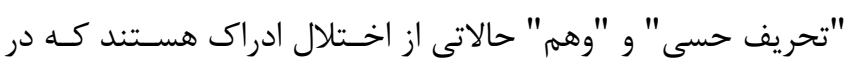

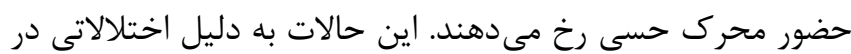

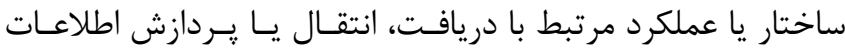

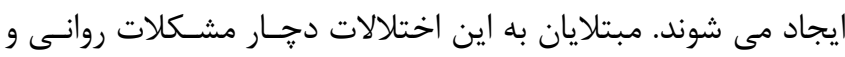
سايكوز نيستند [ها].

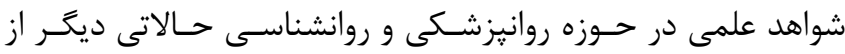

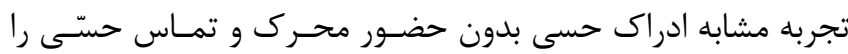

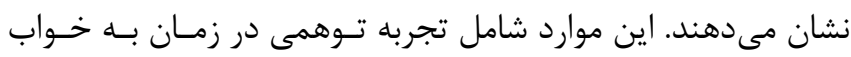

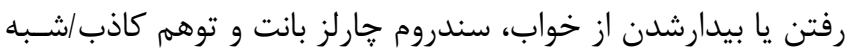

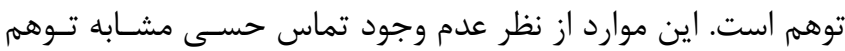
هستند اما افراد تجربه كننده سابقهاى از سايكوز، سوء مصرف مـواد،

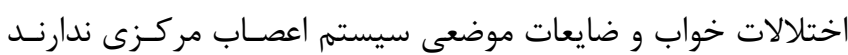

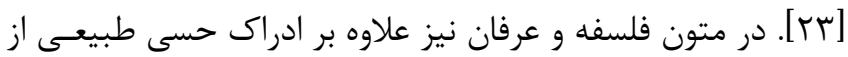

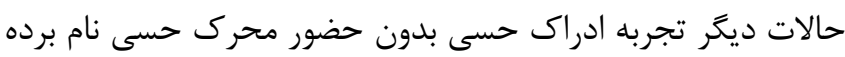

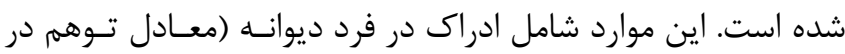

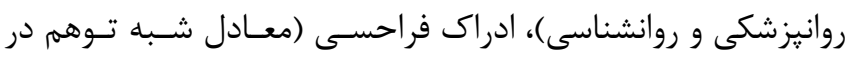

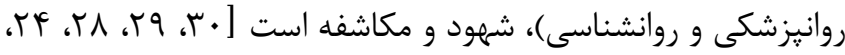

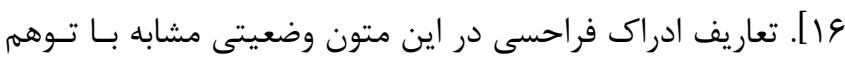

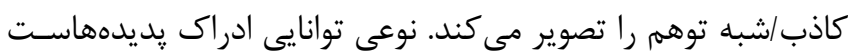

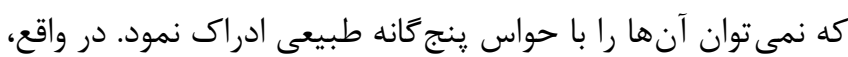


در صـورت عـدم (International Classification of Disease) تشخيص هر كونه بيمارى خاص در فرد داراى تجربه توهمى، فرد در

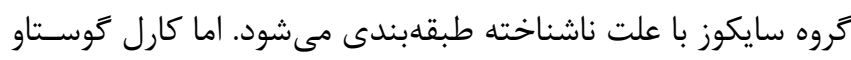

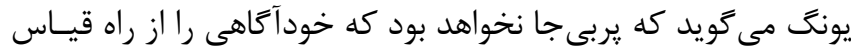

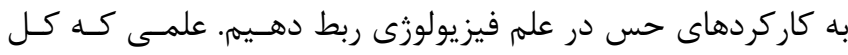

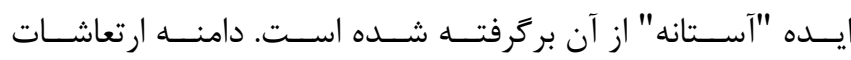

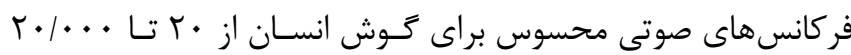

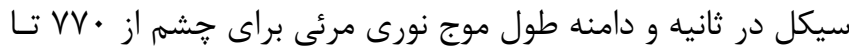

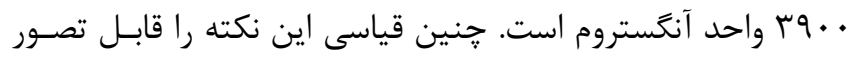

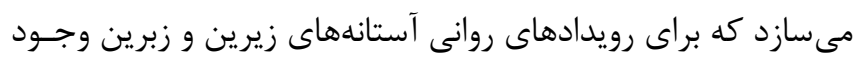

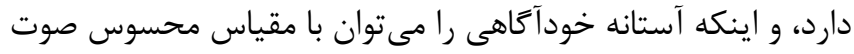
و نور مقايسه كرد كه داراى حد زيرين و زبرين است. شايد بتوان كه

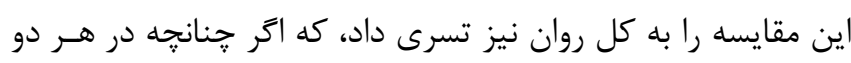

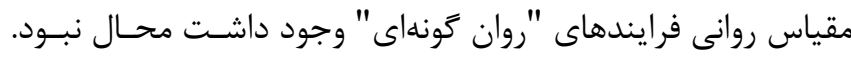

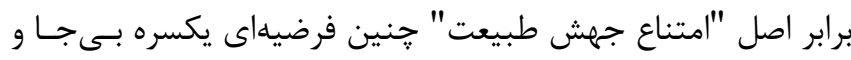

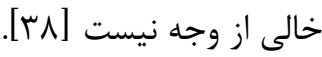

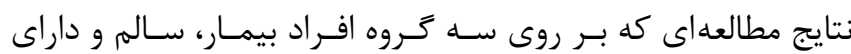

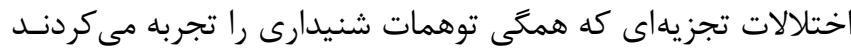
انجام شد نشان داد كه شكل و فرم توهمات شنيدارى در تروه ترهات بيمار

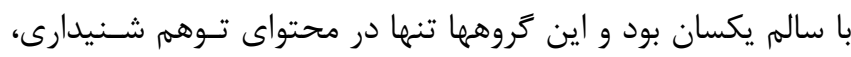

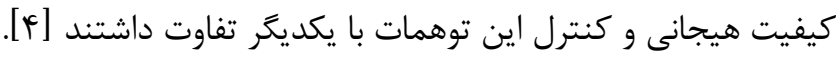

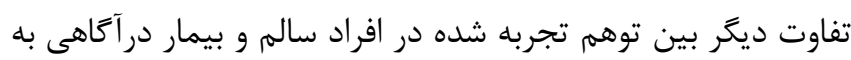

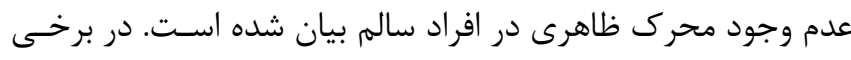
متون اصطلاح توهم كـاذب (ادراى فراحسى) را بــراى آن دسـته از

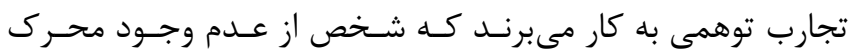

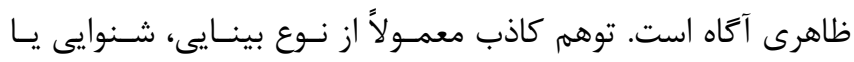

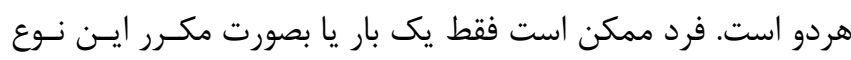

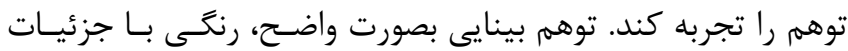

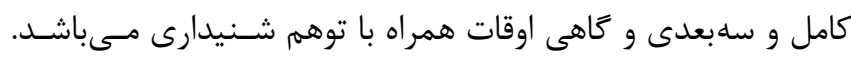

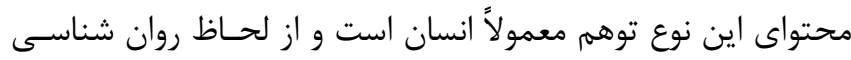

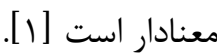

بر اساس تعاريف هر يك از اين حالات و ويزگكىهاى متمـايز كنــده

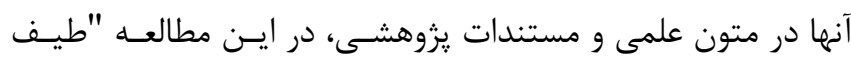

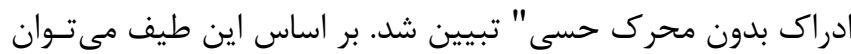

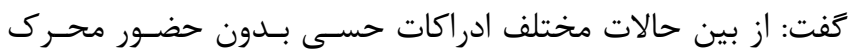

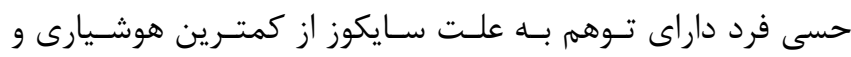

زمان كاهش تحريك حسى، اين سه حالـت از تجربــه مشـابه ادراك

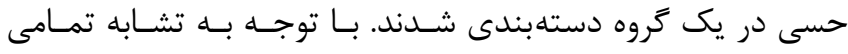

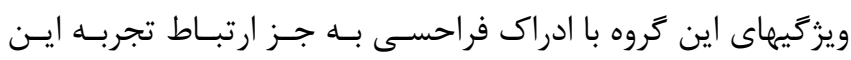

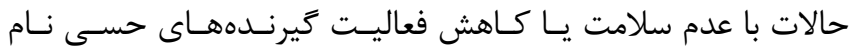

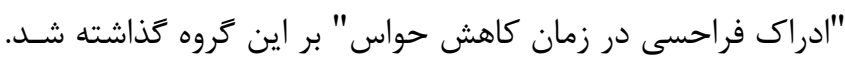

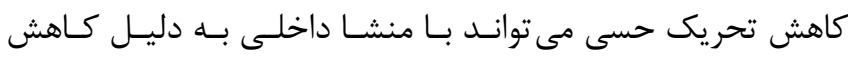

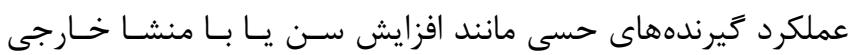

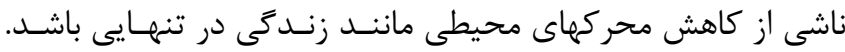

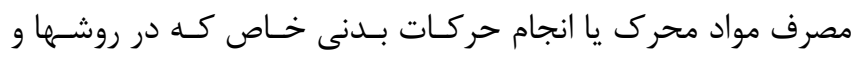

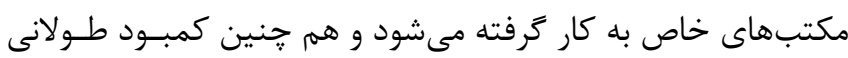
مدت خواب نيز مى تواند تجربه ادراى فراحسى ايجاد نمايد.

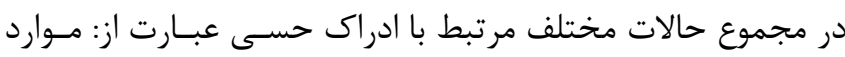

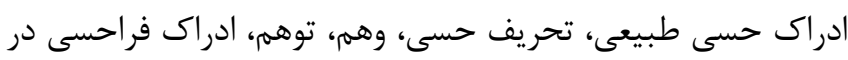
زمان كاهش حواس، ادراك فراحسى و مكاشفه(صـورى و معنـوى)

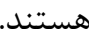

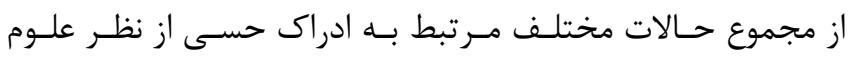

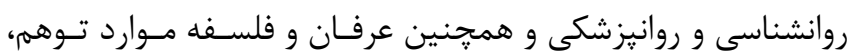

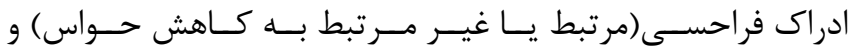

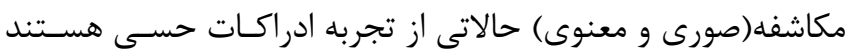

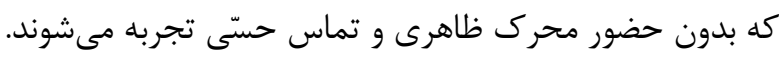

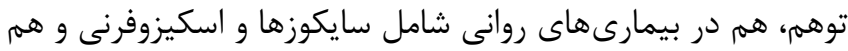

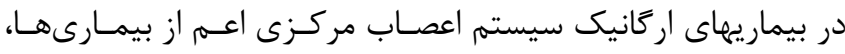

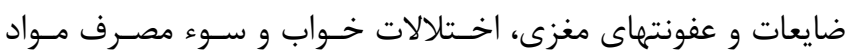

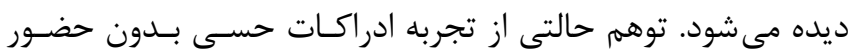

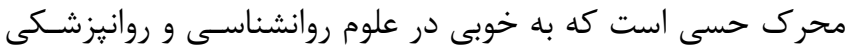
شناخته شده است. شواهد تجربى حاصل از مطالعات و يزوهشهاى علمى بيـانكر تجربــهـ

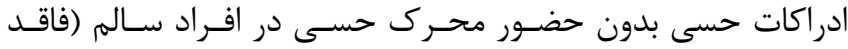

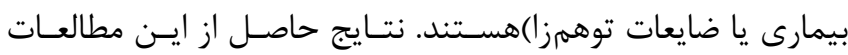

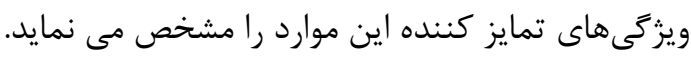

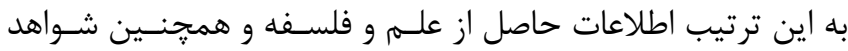

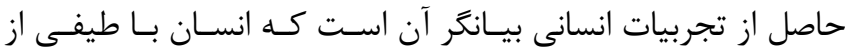

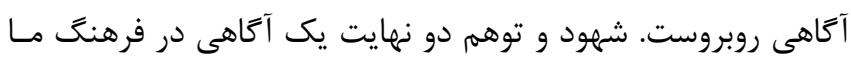

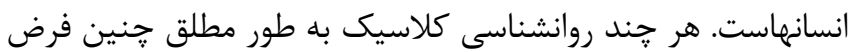
مى كند كه يك حالت عادى آكاهى وجود دارد و ساير حالات آكاهي

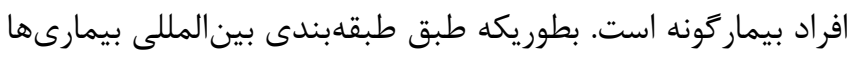


در الكوريتم تشخيص ادراك در نظر گرفته نشدهاند.

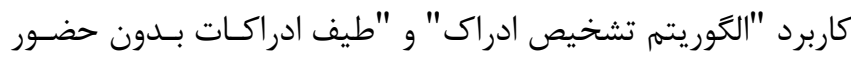

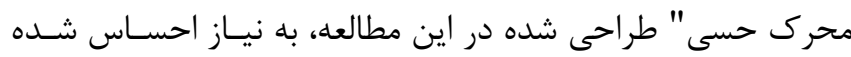

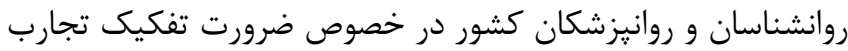

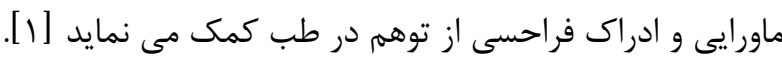

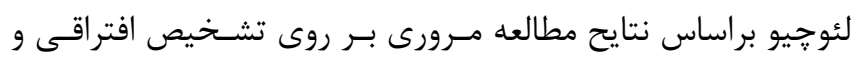

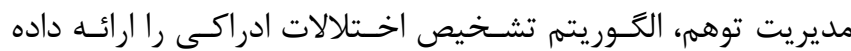

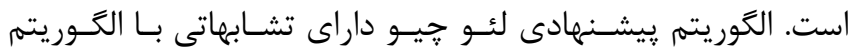

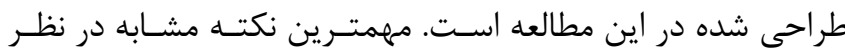
كرفتن ادراك فراحسى (با عنوان توهم كاذب) در الكَريتم است. هم

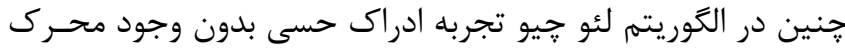

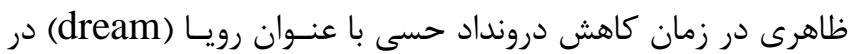

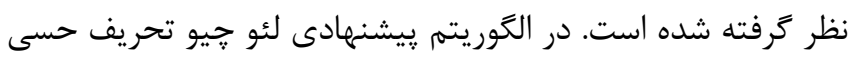
جزء اختلالات در نظر كرفته نشده است [ع]

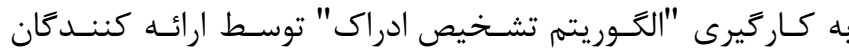

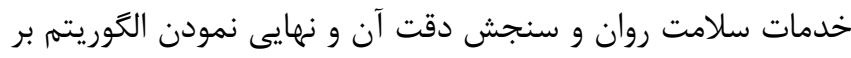

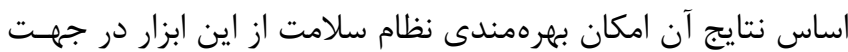
ارتقاى خدمات سلامت روان را فراهم مىنمايد.

\section{سهم نويسند} فرانك فرزدى: طراحى و تدوين مطالعه، اجراى طرح، تدوين كزارش و نغارش مقاله اكرم جهانكير: طراحى و تدوين مطالعه، اجراى طرح، تدوين كزارش و ن منارش مقاله

زيلا صديقى: همكارى در طراحى و اجرا مطالعه و نكارش مقاله علـى اصــر اصــرنزاد فريسـد: مشــاور در طراحى و تدوين مطالعه،

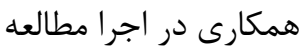
حامدعلى اكبرزاده: تهيه مستندات علمى در حوزه عرفـان و فلسـفه اسلامى، همكارى در اجرا مطالعه و اصلاح مقاله افسون آيين يرست: همكارى در اجرا مطالعه و اصلاح مقاله

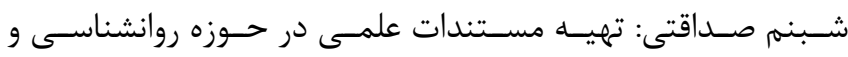
روانيزشكى، همكارى در اجرا مطالعه نئه على اصغر حائرى مهريزى: همكارى در اجرا مطالعه و اصلاح مقاله

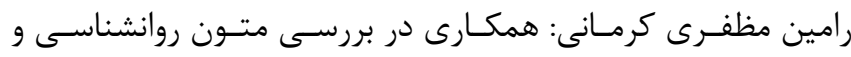

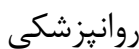

فاطمه رياضى: همكارى در اجرا مطالعه و هماهنكى هاى اجرايى
آكَاهى برخوردار است. فرد داراى مكاشـفه معنـوى بـالاترين سـطح

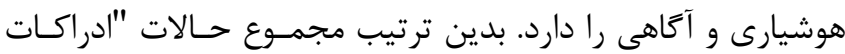

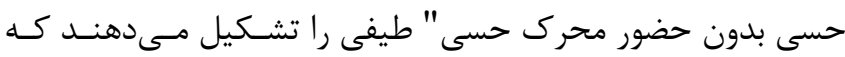
يكى سر آن توهم به علت بيمارى هاى سـايكوتيك (روان يريشىى) و و

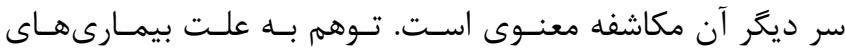

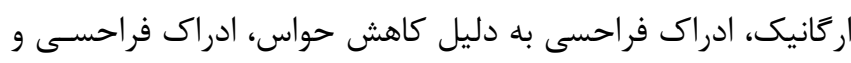

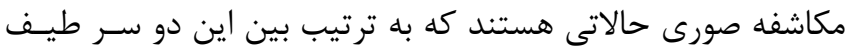

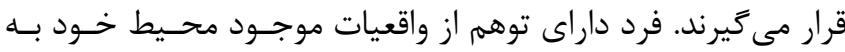

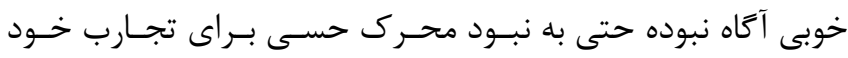

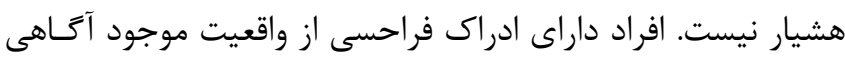

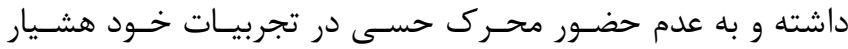

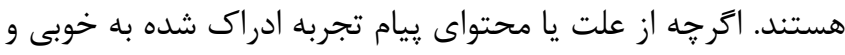

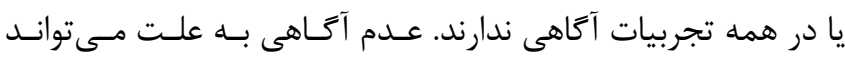

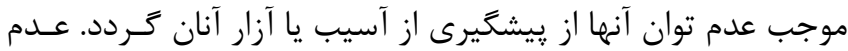

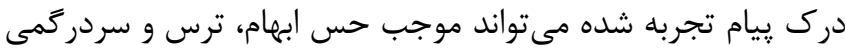

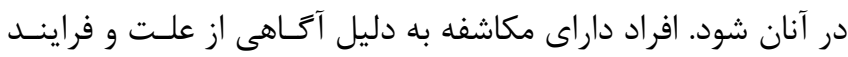
تجارب خود و هم جنين درك پيام اين تجارب به معرفت و شناخت

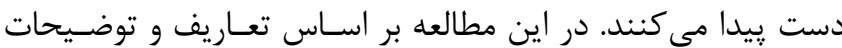
مربوط به هريك از حالات مختلف مرتبط با ادراك حسى، ويزَّيهاى دئن

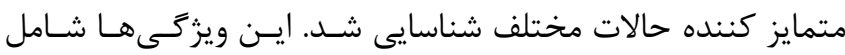
حضور محرك حسى، وضعيت انطبـاق و تناسـب ادراك بـا محـرك

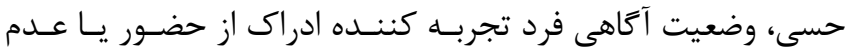

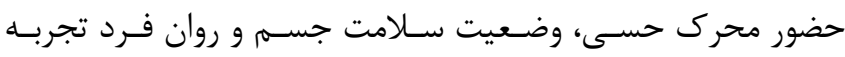
كننده ادراك، آكاهى فرد از يُام تجربه ادراكى است.

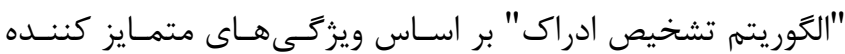

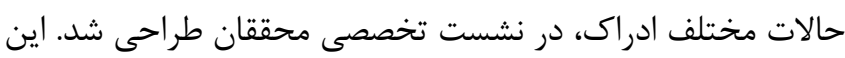

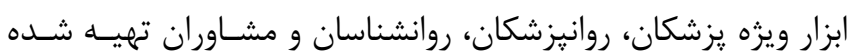

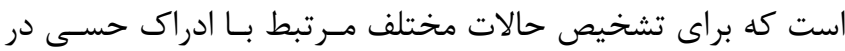

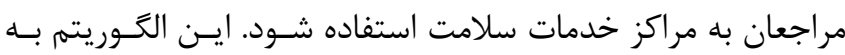

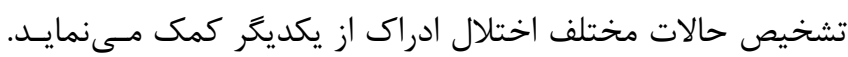

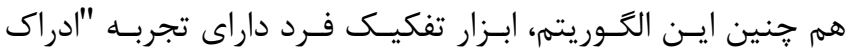

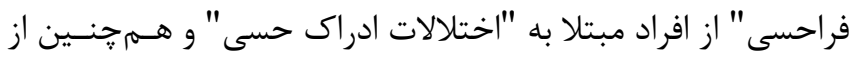

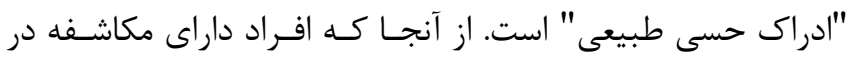

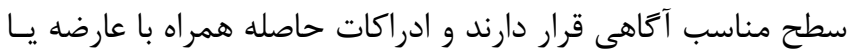

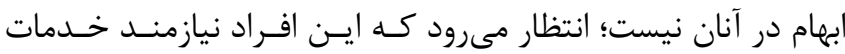

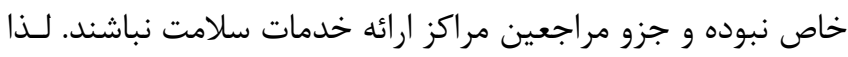




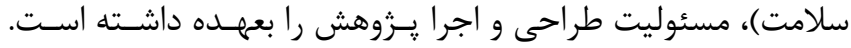

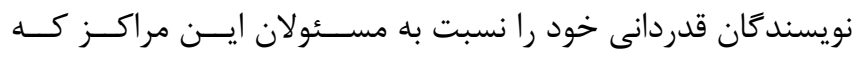

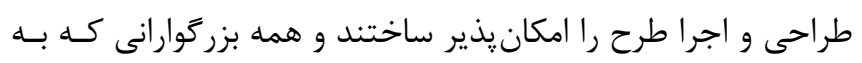

$$
\begin{aligned}
& \text { اجراى طرح يارى رساندند، اعلام مىنمايند. }
\end{aligned}
$$

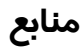

1. Sedman G. A comparative study of pseudo hallucination, imagery and true hallucinations. British Journal of Psychiatry 1966; 112: 9-17

2. VandenBos Gary R. APA concise dictionary of psychology. American Psychological Association: Washington, DC, 2009. Print

3. Sidgwick H, Johnson A, Myers FWH, Podmore F, Sidgwick EM. Report on the Census of Hallucinations. Proceedings of the Society for Psychical Research 1894; 10: 25-422

4. Honig A, Romme MA, Ensink BJ, Escher SD, Pennings MH,deVries MW. Auditory hallucinations: a comparison between patients and non-patients. Journal of Nervous and Mental Disease 1998; 186: 646-651

5. American Psychological Association. Diagnostic and Statistical Manual of Mental Disorders (DSM-5). American Psychological Association: Washington, DC, 2013. Print

6. Leo PW Chiu. Differential diagnosis and management of hallucinations. Journal of the Hong Kong Medical Association 1989; 41: 292-297

7. Rajabi MR. Auditory hallucination. Journal of Audiometry 2003; 12: 46-51 [Persian]

8. Manford M, Anderson F. Complex visual hallucinations, clinical neurobiological insights. Brain 1998; 121: 1819-1840

9. Chen E, Berrios GE. Recognition of hallucinations: a multimensional model and methodology. Psychopathology 1996; 29: 54-63

10. Berrios GE. Tactile hallucination. Journal of Neurology, Neurosurgery and Psychology 1982; 45: 285-293

11. Fujii D, Ahmed I. Characteristics of psychotic disorder due to traumatic brain injury: an analysis of case studies in the literature. Journal of Neuropsychiatry and Clinical Neurosciences. 2002; 14: $130-140$

12. Roshd.ir. perception \& Illusion. Available from: http://daneshnameh.roshd.ir/mavara/mavaraindex.php?page [Persian]

13. Terminology Department. A collection of terms approved by the academy of Persian language and literature (4th volume). $1^{\text {th }}$ Edition, Academy of Persian Language and Literature: Iran, 2007 [Persian]

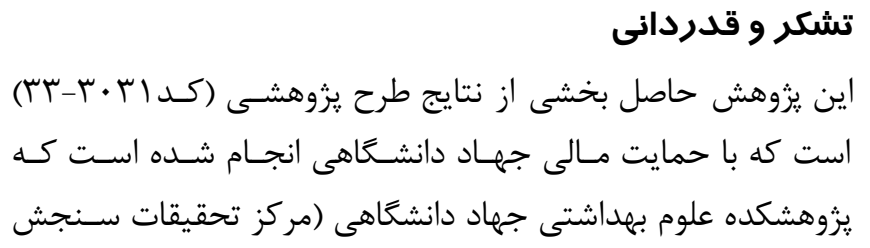

14. PoorAfkari N. Semiotics of mental illness for medical, nursing and psychology students. $11^{\text {th }}$ Edition, Azadeh: Tehran, 2014 [Persian]

15. Iravani M, Khodapanahi MK. Psychology of feeling and perception. $21^{\text {th }}$ Edition, Samt: Tehran, 2018 [Persian]

16. Kalantari E. Super sensory perception and the glorious Quran. Pajuhesh-ha-ye Quran va Hadis (Iranian Journal for the Quranic Sciences \& Tradition) 2010-2011, 43: 133-152 [Persian]

17. Shirazi SM. Resalah Fi-Al-Hodooth. $2^{\text {th }}$ Edition, Sadra Islamic Philosophy Foundation: Tehran, 2015 [Persian]

18. Ibn Sina A, Al-Taelighat. $1^{\text {th }}$ Edition, MaktabAl-Ealam-Al-Eslami: Qom, 1984[Arabic]

19. Elaine A. Psychotherapy and a very sensitive person. $1^{\text {th }}$ Edition, Ashian: Tehran, 2018 [Persian]

20. VandenBos GR. APA dictionary of psychology. $2^{\text {th }}$ Edition. American Psychological Association: Washington, DC, 2007

21. Abolghasemi Dehaghani MR. Perception problems. Scientist Journal 2013; 51:17-20 [Persian]

22. Sadock BJ, Sadock VA. Summary of Psychiatry: Behavioral Sciences - Clinical Psychiatry. $10^{\text {th }}$ Edition, Ayande Sazan, Shahrab: Tehran, 2010 [Persian]

23. Ibn Sina A. Al-nafth Men Ketab Al-Shafa. Maktab-Al-Ealam-Al-Eslami: Qom, 1996 [Persian]

24. Shirazi SM. Al-Hikma Al -muta'aliya Fi-Alasfar Al -'aqliyya Al-arba'a. $3^{\text {th }}$ Edition, Dar Al-Ehya Al-Torath Al-Arabi: Beirut, 1981 [Arabic]

25. De Morsier G. "Le syndrome de Charles Bonnet: hallucinations visuelles des vieillards sans deficience mentale". Ann Med Psychol 1967; 125: 677-701[French]

26. Jafari MT. Tarjome va Tafsire NahjAlbalagha. Vol 7. $1^{\text {th }}$ Edition, Daftare Nashre Farhange Eslami: Tehran, 1997 [Persian]

27. Tabatabayi MH. Shia Dar Eslam. $16^{\text {th }}$ Edition Boostane Ketab: Qom, 2018 [Persian]

28. Paya A. Analytical philosophy, issues and 
perspectives. $2^{\text {th }}$ Edition, Tarh-e No: Tehran, 2005. P476 [Persian]

29. Copleston FCh. History of philosophy. $5^{\text {th }}$ Edition. Elmi-Farhangi Soroosh: Tehran, 9:211-238, 1996 [Persian]

30. Qunawi S. Fokook. 1st Edition, Mowla: Tehran, 1992 [Persian]

31. Ibn Arabi M. Fotoohate-Makie. Vol 1. $6^{\text {th }}$ Edition, Mowla: Tehran, 2018 [Persian]

32. Ashjaa M, Mystical Revelation. Religion \& Mysticism 2009; 20: 135-163 [Persian]
33. Stace WT. Mysticism and philosophy $9^{\text {th }}$ Edition, Soroush: Tehran, 2008 [Persian]

34. Benjamin, J. Sadock, M.D. Kaplan \& Sadock's pocket handbook of clinical psychiatry. $6^{\text {th }}$ Edition. Wolters Kluwer: Philadelphia, 2010

35. Hallgin RP, Whitburn SC. Psychopathology. $25^{\text {th }}$ Edition, Ravan: Tehran, 1: 2020 [Persian]

36. Mesbah MT. Amoozesh Falsafe. $18^{\text {th }}$ Edition, Amirkabir: Tehran, 2017 [Persian]

37. Jung CG. On the nature of the psyche. $2^{\text {th }}$ Edition, Behjat: Tehran, 1996 [Persian] 